\title{
Preferences for International Redistribution: The Divide over the Eurozone Bailouts
}

\author{
Michael M. Bechtel University of St.Gallen \\ Jens Hainmueller Stanford University \\ Yotam Margalit Tel Aviv University
}

\begin{abstract}
Why do voters agree to bear the costs of bailing out other countries? Despite the prominence of public opinion in the ongoing debate over the eurozone bailouts, voters' preferences on the topic are poorly understood. We conduct the first systematic analysis of this issue using observational and experimental survey data from Germany, the country shouldering the largest share of the EU's financial rescue fund. Testing a range of theoretical explanations, we find that individuals' own economic standing has limited explanatory power in accounting for their position on the bailouts. In contrast, social dispositions such as altruism and cosmopolitanism robustly correlate with support for the bailouts. The results indicate that the divide in public opinion over the bailouts does not reflect distributive lines separating domestic winners and losers. Instead, the bailout debate is better understood as a foreign policy issue that pits economic nationalist sentiments versus greater cosmopolitan affinity and other-regarding concerns.
\end{abstract}



he global financial system is in the midst of its most severe crisis in the postwar era, with countries such as Greece, Portugal, Ireland, and Spain facing possible sovereign defaults. ${ }^{1}$ To prevent such defaults and a subsequent economic collapse, other eurozone countries have been asked to contribute massive sums to a financial bailout fund. Although most experts view such bailouts as necessary for averting catastrophe, many voters fiercely oppose a large transfer of their tax contributions to prop up other countries' public finances. Indeed, recent snap polls in Germany and France reveal a sharply divided public, with only about one-in-three voters willing to support the bailout program. ${ }^{2}$ How should we understand the public divide over providing assistance to the region's struggling economies? What explains the variation in voters' support for the bailouts? This article provides the first systematic analysis of the determinants of voter preferences on this major new form of international redistribution.

We draw upon three strands of literature to develop a set of theoretical explanations for the public divide over the bailouts. The first account centers on the distributive effects of the bailouts, the second on voters' social dispositions, and the third on the role of partisanship and political knowledge. We then test a set of predictions stemming from each of these three accounts using novel data from two large-scale surveys that we conducted in Germany, the country shouldering the largest share of the EU's bailout program. The surveys, carried out in early 2012 , included a broad range of detailed items pertaining

Michael M. Bechtel is SNSF Research Professor and Assistant Professor of Political Science, University of St.Gallen, Rosenbergstrasse 51, CH-9000, St. Gallen, Switzerland (mbechtel.mail@gmail.com). Jens Hainmueller is Professor of Political Science, 616 Serra Street, Encina Hall West, Room 100, Stanford, CA 94305-6044. (jhain@stanford.edu). Yotam Margalit is Professor of Political Science, Tel Aviv University, Tel Aviv 69978, Israel. (ymargalit@tau.ac.il).

We thank Adam Berinsky, Tobias Boehmelt, James Davis, Jude Hays, Alex Kuo, Noam Lupu, Pablo Pinto, Benjamin Raich, Frank Schimmelfennig, Christina Schneider, David Singer, Juerg Vollenweider, Catherine de Vries, and audiences at University of California San Diego, University of Pittsburgh, Juan March Institute in Madrid, The Hebrew University of Jerusalem, University of St.Gallen, Oxford University, and Yale University for helpful comments. We gratefully acknowledge financial support by ETH Zurich's Cooper Fund. Michael M. Bechtel gratefully acknowledges support by the Swiss National Science Foundation (grant \#PP00P1-139035). Stefan Brunner, Quynh Nguyen, and Bernhard Reinsberg provided valuable research assistance. The usual disclaimer applies.

${ }^{1}$ Replication data and supporting information are available online on the Dataverse Network at http://hdl.handle.net/1902.1/21782.

2"Mehrheit gegen stärkere Finanzhilfen für verschuldete EU-Staaten,” Politbarometer Dezember II 2010, 12/17/2010; "French People Oppose Second Greek Bailout, Ifop Poll Shows,” Bloomberg News, 09/17/2011; “Germany Backs Greece Aid, but at a Cost to Merkel,” New York Times, 02/27/2012.

American Journal of Political Science, Vol. 00, No. 00, xxx 2014, Pp. 1-22

(C)2014, Midwest Political Science Association

DOI: 10.1111/ajps.12079 
to respondents' objective and subjective economic conditions, as well as their attitudes toward various aspects of the crisis, allowing for direct tests of the different theoretical accounts.

A central finding in our study is that economic selfinterest, measured using a broad range of indicators, explains little of the variation in individual preferences on the eurozone's financial rescues. Rather, we present experimental evidence that is more consistent with the notion that voters' worry about the economic costs of the bailouts reflects a sociotropic concern about the overall burden that Germany will shoulder. However, the strongest predictors of preferences over the bailouts are measures of voters' social dispositions, specifically their cosmopolitan outlook and altruistic inclination. The strength and consistency of these empirical associations suggests that voters mainly assess these financial rescue transfers along dimensions other than the expected consequences of the transfers on their own economic standing.

Finally, we find that, to a lesser degree, partisan orientations also help account for some of the variation in individual attitudes towards the eurozone bailouts. Notably, support for these financial transfers exhibits a crosscutting ideological pattern: rather than a left-right divide, attitudes differ most significantly between supporters of centrist parties and extremist parties, whereby the latter are significantly less supportive of the bailouts.

We conduct a broad range of robustness checks, including a replication of the results based on stated attitudes toward the bailouts using a second, quasibehavioral measure. This measure captures respondents' willingness to sign up to have a message with their personal details sent on their behalf to their legislator, expressing their position on the bailouts. The results using this arguably more "costly" measure are reassuringly similar. In addition, we examine the study's external validity by augmenting the results from our online survey with a second, nationally representative phone survey that we fielded at the same time. Again, the results reveal similar findings.

Much of our analysis uses observational data. The limits for drawing causal inference based on such data have been well rehearsed. Nonetheless, our findings reveal a notable weakness of some theoretically predicted correlations and, in contrast, a robust presence of others. These empirical patterns thus allow us to assess the relative validity of different theoretical explanations. Furthermore, our results also offer guidance regarding the factors that merit further experimental investigation. Such an investigation would more effectively demonstrate the causal effect of these factors on shaping voters' attitudes on international bailouts.
In sum, then, our analysis suggests that the public division over the bailouts does not reflect a distributive conflict between the expected winners and losers from these financial transfers. Instead, the bailouts are better understood as a foreign policy issue that pits economic nationalist sentiments versus other-regarding concerns and greater orientation towards other Europeans. In the concluding section, we comment on the implications of the results for both theory and policy.

\section{The Politics of the European Debt Crisis}

In December 2009, the entering socialist government of Greece announced that its predecessor had massively underreported the country's debt. The revised assessment revealed a debt of over $€ 300 \mathrm{bn}$, amounting to $113 \%$ of the GDP, nearly twice the eurozone's limit of $60 \%$. Despite the Greek president's assurances that the country was "not about to default on its debt," rating agencies downgraded Greek bank and government debt. Soon after, concerns about other debt-exposed EU economies, primarily those of Ireland and Portugal, led eurozone countries to consider action over Greece's debt. The idea of providing a financial bailout for Greece met immediate resistance among publics in the region, but after contracted negotiations, the eurozone governments and the IMF agreed in March 2010 to provide a financial safety net of $€ 22$ bn for Greece, a sum that was soon revised up to $€ 30 \mathrm{bn}$. Yet, the rapid deterioration of the situation, including violent protests in Athens, led negotiators to further increase the bailout package, and by early May, they announced a $€ 110$ bn financial rescue for Greece.

Driven by the fear that the crisis could spread to other indebted countries, and after lengthy negotiations with considerable discord, European leaders agreed upon a temporary bailout fund of $€ 440$ bn, the European Financial Stability Facility (EFSF). ${ }^{3}$ Each eurozone country had to individually ratify the agreement and contribute to the fund proportionally. Germany, the largest eurozone economy, would shoulder the largest share, approximately $27 \%$.

As the initial EFSF funds proved insufficient to contain the unfolding crisis in Ireland ( $€ 85$ bn bailout) and later Portugal ( $€ 78$ bn bailout), eurozone finance ministers negotiated a new, permanent bailout fund, called

\footnotetext{
${ }^{3}$ The EFSF had a notional $€ 440$ bn euros at its disposal, but it could only lend out approximately $€ 250$ bn because of the amount it was required to maintain in order to keep its borrowing costs low.
} 
the European Stability Mechanism (ESM), worth close to $€ 500 \mathrm{bn}$. Yet worries continued to grow about the ability of the larger eurozone economies, primarily Italy and Spain, to service their debts. These concerns led to renewed calls to further expand the bailout fund; however, the calls faced strong resistance from Angela Merkel, the German Chancellor. Other proposals for protecting the region's economy, in particular the idea to issue $\mathrm{Eu}-$ robonds that would enhance the eurozone's lending capacity, also experienced strong opposition by the German government, which argued that such bonds could substantially raise the country's liabilities in a debt crisis. ${ }^{4}$ At the same time, growing threats from members of the governing coalition to oppose the expansion of the bailout fund raised questions about Merkel's political ability to lead an effective response to the crisis.

In October of 2011, European leaders eventually announced a "three-pronged" agreement that included bank recapitalization, a "haircut" by private lenders to Greece of 50\%, and the expansion of the bailout fund to $€ 1$ trillion. ${ }^{5}$ This fund invests in and guarantees government bonds from countries such as Spain and Italy. While the long-term impact of this agreement remains to be seen, the ongoing eurozone crisis continues to provoke calls for further bailouts.

The situation confronting the eurozone and the attempts to coordinate international transfers of such magnitude are an unprecedented phenomenon in the postwar era. ${ }^{6}$ The key question is whether skeptical publics in donor countries will provide sufficient political backing to allow further bailouts. The answer is unclear, as a sizable share of citizens in major donor countries express strong opposition to the rescue funds. ${ }^{7}$ To understand the factors underlying the public sentiments on this issue, the next section lays out a number of theoretical perspectives that may account for the observed variation in individual support for the bailouts.

\footnotetext{
${ }^{4}$ See, for example, "The Return of Madame Non: Why Merkel Remains Opposed to Euro Bonds," Spiegel Online, 11/24/2011.

${ }^{5}$ The term "haircut" refers to the size of the loss that lenders suffer on the loans and interest they are owed.

${ }^{6}$ According to the calculations of the German economist HansWerner Sinn, "Greece has received a staggering 115 Marshall plans, 29 from Germany alone" ("Why Berlin Is Balking on a Bailout," New York Times, 12/6/2012).

7 "Mehrheit gegen stärkere Finanzhilfen für verschuldete EUStaaten," Politbarometer Dezember II 2010, 12/17/2010; "French People Oppose Second Greek Bailout, Ifop Poll Shows," Bloomberg News, 09/17/2011; "Germany Backs Greece Aid, but at a Cost to Market," New York Times, 02/27/2012.
}

\section{Public Attitudes on International Bailouts}

The literature on the determinants of public opinion on foreign economic policy has developed substantially in recent years. However, no published study to date has systematically explored the divide in public opinion over the provision of international financial bailouts. Although this issue represents largely uncharted territory, one may still gain insights from related work examining the determinants of voter preferences on other international economic interactions such as trade, immigration, and foreign aid. We draw on three strands of literature to derive a set of explanations for the formation of public attitudes on the bailouts. The first explanation centers on economic self-interest as the main determinant of attitudes. The second approach focuses on social dispositions, in particular, altruism and cosmopolitanism, and the third perspective emphasizes the influence of partisan orientation and political knowledge.

\section{Economic Self-Interest}

A common claim in the political economy literature holds that voters' preferences on economic policy depend on the expected effects of the policy on their own economic standing. Put simply, individuals who personally expect to gain from a given policy will support it, while potential losers will oppose it. Several studies have recently extended this claim, which lies at the core of work on the politics of taxation and redistribution, to also explain preferences on foreign economic policies. Various studies argue that voters' opinions on policies such as trade (Hays, Ehrlich, and Peinhardt 2005; Mayda and Rodrik 2005; Scheve and Slaughter 2001a), immigration (Scheve and Slaughter 2001b), or European integration (Gabel 1998; Tucker, Pacek, and Berinsky 2002) are largely a function of individuals' expectations about how the proposed policy would affect their future earnings. In the same vein, other studies argue that the material self-interest of the constituents can also account for the positions legislators take on foreign economic policies (Broz 2005; Milner and Tingley 2011). For example, Broz (2005) analyzes roll-call votes on bills proposed to restrict financial rescues by the Exchange Stabilization Fund of the U.S. Treasury Department and offers evidence that members of Congress are significantly more likely to support the rescues when their district is likely to benefit from them. Relatedly, Curtis, Jupille, and Leblang (2012) study attitudes of voters in Iceland in the context of the second "Icesave" referendum 
and find that in addition to other factors, support for the country's international debt-resettlement program was closely tied to voters' own economic interests.

Applying the economic self-interest logic to explain variation in support for international bailouts requires theorizing about how voters assess the likely impact of a bailout (or lack thereof) on their own economic situation. In the absence of an agreed-upon economic model of the bailouts' distributive effects, we begin by laying out several channels through which bailouts could affect the personal standing of voters, given their specific position in the economy. To do so, a useful point of departure is the fact that these large bailouts need to be financed somehow. This can happen in at least one of three ways: (a) by raising taxes; (b) by reducing spending on domestic programs; or (c) by borrowing. These channels are relevant mainly for how individuals perceive the impact of the bailouts on their income from labor and public-transfer programs. However, individuals' income streams can also depend on (d) the assets they own or (e) the extent to which their jobs depend on business with other European countries. Therefore, bailouts can affect citizens' economic wellbeing by helping avert a collapse in the value of financial assets and by sustaining trade within the eurozone. Each of these mechanisms has different implications for how voters might assess the desirability of the bailouts.

As noted, preferences for domestic redistribution are often assumed to depend on voters' own economic standing: net beneficiaries of a transfer are expected to support the policy while net contributors should oppose it (Alesina and Ferrara 2005; Corneo and Grüner 2002). This logic predicts that support for redistributive policies will correlate negatively with income, since high-income individuals have to finance the bulk of the transfers to the poor. If high earners perceive international bailouts as transfers that will require financing through higher taxation, then the same prediction might also apply in the case of international transfers: all else equal, we might expect that high-income individuals would exhibit greater opposition to the bailouts than low-income individuals.

Domestic redistribution and welfare transfers benefit poorer domestic constituencies (Alesina and Ferrara 2005). In contrast, international financial transfers provide immediate benefits to individuals in the receiving countries but (at best) assist the population in the donor countries only indirectly. As a result, voters that expect these transfers to reduce the financial resources available for domestic assistance programs are more likely to oppose contributions to international bailouts. This logic suggests that individuals with a higher probability of dependence on social transfers-low-income, unemployed, or workers employed in struggling sectors-should most strongly oppose the bailouts. Yet if both the "transfers funded by taxes" mechanism and the "reduced domestic spending" account are correct, one would expect to observe a U-shaped pattern of support: respondents in the middle income category will, ceteris paribus, exhibit a greater degree of support for the bailouts than both low and high earners.

In the context of domestic redistribution, we also note the significant geographic variation in economic prosperity across Germany, which means that some regions (Länder) are net receivers of federal transfers while other regions are net contributors, subsidizing the federal government's assistance to less well-off parts of the country. Support for bailouts should be lower in net receiving regions, since residents might worry that international financial transfers would come at the expense of transfers to their own region.

A third approach for financing the transfers, at least in the short-term, is by borrowing. Policy makers may find this approach attractive because it does not immediately impose the costs of the bailouts on their domestic constituents. However, borrowing implies that the burden of financing the bailouts will fall mostly on the younger cohorts, who will have to pay the lenders back in the future. Thus, financing bailouts through borrowing results in an intergenerational redistribution of the costs. If this mechanism underlies the way voters assess the bailouts, we should observe an intergenerational divide: younger voters oppose the bailouts more strongly than older voters since the former expect to shoulder much of the future costs.

Individuals might assess the impact of the bailouts also through the likely effect of a financial meltdown on the financial assets they own, such as stocks. For example, Scheve and Slaughter (2001b) argue that since trade policy affects house prices through regional housing demand, economic policy preferences may also depend on home ownership. In the context of the current crisis, individuals who have invested in financial assets such as stocks would stand more to lose from a market crash following sovereign defaults in the eurozone. Therefore, individuals with stock investments would be more likely to support an international financial rescue program that would stabilize financial markets.

Economic openness can affect employment security and consequently influence individuals' political preferences (Margalit 2011; Scheve and Slaughter 2004). However, individuals differ in the extent to which their own employment situation depends on international trade fluctuations. In the case of the bailouts, attitudes might reflect the degree to which individuals perceive the eurozone crisis to affect their job security. In particular, those 
whose jobs depend on substantial trade and business ties with neighboring EU countries could view their employment as being more vulnerable to a deterioration in the region's economies. As a result, individuals working in sectors whose performance strongly depends on trade with other EU countries should exhibit greater support for the bailouts than individuals employed in sectors that rely less on such trade ties.

\section{Social Dispositions and Traits}

The eurozone bailouts aim at stabilizing the EU's common currency and preventing a financial meltdown. A country's financial transfers to the bailout fund therefore resemble a contribution to an international public good, in that the benefits from the fund are nonexcludable and each country could gain by "free riding" on other countries' contributions to the fund. Previous research from lab experiments suggests that other-regarding motivations such as altruism affect individuals' willingness to contribute to public goods and to charity (Fehr and Schmidt 2006; Vigna, List, and Malmendier 2012). This finding may apply also outside the lab to our case of interest: altruism, narrowly defined here as "the willingness to incur a loss of material welfare to enhance the welfare (material or not) of others" (Elster 2006, 186) may also be important for explaining why some individuals are more supportive of the bailouts. Note that this definition is agnostic about the motivation for altruism: it may reflect an other-regarding concern, but it could also arise from adherence to a norm or from the satisfaction one derives from the act of giving (the "warm glow" effect). ${ }^{8}$ Either way, individuals with stronger altruistic inclinations are more likely to take actions that exhibit a greater concern for the well-being of others. They are, therefore, also expected to be more supportive of a policy assisting individuals in other countries in crisis.

Since bailouts are a form of international redistribution, another social disposition potentially relevant for this analysis is citizens' degree of cosmopolitanism. By "cosmopolitanism" we refer to the extent to which people have an interest in, and orientation towards, groups of individuals who are distant from them, geographically or culturally, as opposed to a local orientation that extends only to one's more immediate community. Prior research shows that a measure of whether individuals are more cosmopolitan helps account for their attitudes on economic openness, particularly on policies such as trade

${ }^{8}$ See Elster (2006) for a comprehensive discussion of the definitional aspects of altruism. and immigration (Hainmueller and Hiscox 2006, 2007; Margalit 2012). ${ }^{9}$

\section{Partisan Orientation}

Since individuals often possess little knowledge about complex policy issues, they tend to rely on informational shortcuts, such as partisan "cues," when forming their opinions, i.e., they adopt the position their preferred party or politician takes on a given issue (Druckman 2001; Lupia 1994). How would such partisan cuing be reflected in public opinion over the bailouts? One possibility is that public opinion over the bailouts, a form of international redistribution, reflects a left-right divide similar to the one observed with respect to domestic redistributive policies. According to this view, parties and voters on the right will oppose providing financial assistance to other countries while those on the left should support the bailouts. ${ }^{10}$

Alternatively, the eurozone bailouts may separate the center from the ideological extremes, much like the debate over EU integration separates the center from the ideological extremes (Hooghe, Marks, and Wilson 2002; Markowski and Tucker 2005). Rather than a left-right divide, partisans on either the far left (i.e., voters of Linke) or the far right (NPD) would oppose the bailouts whereas voters of the centrist parties would be more supportive. There are at least two reasons for this expectation. First, similar to the issue of EU integration more generally (Hix 1999), EU bailouts have been promoted primarily by the mainstream parties. The debate over the bailouts may therefore present an opportunity for voters of peripheral parties to express their dissatisfaction with the mainstream. Second, the bailouts entail policies that might seem particularly objectionable to voters on the two extremes. The far left might object to the demand for deep austerity measures that afflict the most vulnerable segments of the population in the recipient countries, while the far right might oppose the bailouts because

\footnotetext{
${ }^{9}$ Other work found that related dispositions such as ethnocentrism or nationalism help account for voter preferences on trade and immigration (Mansfield and Mutz 2009; O’Rourke and Sinnott 2001). Moreover, a substantial body of work, mostly drawing on the American context, has shown evidence that broader otherregarding attitudes play an important role in determining foreign policy preferences on other specific issues (Holsti and Rosenau 1990; Hurwitz and Peffley 1987; Rathbun 2007).

${ }^{10}$ This expectation is consistent with previous work arguing that the left-right distinction helps explain variation in foreign policy preferences more generally: voters on the left harbor stronger internationalist sentiments while voters on the right are more isolationist with respect to international engagement (Noël and Thérien 2008; Quinn and Toyoda 2007)
} 
they imply diverting the nation's funds to benefit the citizens of other countries.

\section{Data and Measurement}

Our main analysis draws upon an original survey that we fielded online to a sample of 5,000 German voters in early January of 2012. To assess the external validity of the results, we also added our main attitudinal measures to a national telephone survey. ${ }^{11}$ The phone sample contained 1,000 interviews with voters who were recruited using random-digit dialing. The phone survey had a response rate of $45.1 \%$ and was fielded during the same days as the online survey. Similar to most other surveys based on Internet panels, our online sample is somewhat skewed towards younger, more educated, and male voters compared to the total voter population. The demographics of the phone survey sample are more closely representative of the general voter population, except for a slight skew toward more educated respondents. To address these imbalances, we use entropy balancing (Hainmueller 2012; Hainmueller and $\mathrm{Xu} 2013$ ) to reweight the data from the online and phone survey to match the demographic margins from the voter population. We use the weighted samples for all subsequent analyses. (Table S.1 in the online supporting information shows the demographics of the unweighted and reweighted online and phone survey samples as well as the general voter population.) Below we also compare the attitudes expressed in the online and phone samples and find that respondents provided comparable answers and exhibited a similar relationship between key covariates and attitudes toward the bailout.

We use two questions to measure attitudes towards the bailouts. The first question is:

"Now we would be interested in your opinion about the current financial and debt crisis. As you may know, the EU countries have agreed to establish a financial rescue fund which can be used to make bailout payments to over-indebted EU countries. In general, are you in favor or against bailout payments for over-indebted EU countries?"

The answer categories ranged from 1 ("very much in favor") to 5 ("very much against"). We refer to this measure as Against Bailouts. While this item measures general attitudes towards the bailout, we also use a second measure

\footnotetext{
${ }^{11}$ The survey was fielded between January 2 and 5, 2012. Respondents were recruited by Respondi, an international survey firm. The telephone survey was conducted by IPSOS.
}

that captures attitudes towards the size of the German contribution to the fund:

"Should Germany pay more or less money into the European financial rescue fund, which is used to provide bailout payments to over-indebted EU countries? Do you think Germany should pay in much more, pay in somewhat more, pay in neither more nor less, pay in somewhat less, or pay in much less?"

We code the answers in the same direction from 1 ("pay in much more") to 5 ("pay in much less") and refer to this variable as Pay In Less.

We use several measures to capture the factors that may predict attitudes towards financial bailouts. The predictors include a battery of sociodemographic variables that measure a respondent's age (five age groups), highest educational attainment (four groups), and gender. We include a set of variables to capture potential self-interested economic concerns that correspond to each of the mechanisms described in the theoretical section: household income (divided into five groups), employment status, stock investment, net beneficiary of regional transfers, self-reported strength of the employer's trade ties with EU countries, and several export, import, and trade dependence measures based on respondents' industry of employment (measured using responses to open-ended questions which we classified at the two-digit level of the official German industry classification). The supporting information provides variable definitions, the question wording, and/or data sources for all variables.

As an indicator of respondents' level of altruism, we employ a quasi-behavioral measure constructed as follows: we informed respondents that an Amazon voucher of 100 euros would be raffled among the survey participants. Respondents were then told that they can select to donate some fraction of their (potential) winnings to a charitable donation of their choice; in case they win, the donated amount will be deducted from their voucher. Respondents who chose to donate some portion of their remuneration could then select their preferred option for charity out of a menu of 30 organizations and indicate the fraction that they wish to donate. About one-third of the respondents (35\%) chose to donate at least some portion of the earnings, and among those, the median donation was $50 \%$ of the total sum (with notable clustering also at $10 \%, 25 \%$, and $100 \%)$. For our analyses, we partition respondents into three groups: respondents who chose not to donate at all, those who chose a donation between 1 and $50 \%$, and individuals who selected a donation greater than $50 \%$. 


\section{TABle 1 Attitudes towards Financial Bailouts}

How much are you in favor or against bailout payments for over-indebted EU countries?

\begin{tabular}{lrlr}
\hline Strongly in favor & $3.0 \%$ & Pay in much more & $0.5 \%$ \\
Somewhat in favor & $24.5 \%$ & Pay in somewhat more & $4.0 \%$ \\
Neither in favor nor against & $10.2 \%$ & Pay neither more or less & $25.4 \%$ \\
Somewhat against & $40.1 \%$ & Pay in somewhat less & $34.2 \%$ \\
Strongly against & $20.9 \%$ & Pay in much less & $32.6 \%$ \\
Don't know & $1.5 \%$ & Don't know & $3.4 \%$
\end{tabular}

Note: $\mathrm{N}=4,499$. Results are weighted by the sample adjustment weights so that the education, age, and gender margins match the total voter population (see text for details).

To measure cosmopolitanism, we use a question from the Local Cosmopolitan Scale (Dye 1963) that captures the extent to which respondents think that national and international happenings are more or less interesting than events that occur within their local community. This measure taps into the original formulation of the concept as defined in Merton (1968) who described cosmopolitanism as an orientation towards the world rather than one's local community. ${ }^{12}$ Importantly, the measure we use captures cosmopolitanism as something distinct from altruism in that we intentionally do not ask about a sense of empathy for others. Indeed, in our sample, the measures of altruism and cosmopolitanism correlate positively but weakly (a correlation coefficient of .11).

We measure partisan orientation by asking respondents which party they would vote for if federal elections were held on the upcoming Sunday. The first is a standard general-knowledge question that asks respondents regarding the method of allocating seats in the Bundestag; of four possible answers, about half of the respondents correctly answered this question, and we code it as a binary variable. The second knowledge variable measures specific knowledge about the bailouts. Here, we provide respondents with a list of six possible countries and ask them to identify the countries that received financial assistance from the European bailout fund. ${ }^{13}$ Based on their responses, we code a binary variable that takes the value of 1 for respondents who correctly classified at least two of the three countries that received bailout payments and did not mark any of the three countries that did not receive bailout payments or the "do not know" option. ${ }^{14}$

\footnotetext{
${ }^{12}$ Altruism and cosmopolitanism were measured close to the end of the survey to prevent downstream effects.

${ }^{13}$ The list of countries is Portugal, Ireland, Greece, Slovakia, Netherlands, France, and "do not know."

${ }^{14}$ About $24 \%$ correctly classify all three, and $26 \%$ correctly classify two out of three.
}

\section{The Correlates of Opposition to Bailouts}

Table 1 shows the responses for both outcomes in the online sample. A clear majority of respondents opposes transfers to the struggling eurozone countries, while $24.5 \%$ are somewhat in favor and about $3 \%$ are strongly in favor of the bailouts. Opposition to the bailouts is even more pronounced when we ask about the German contribution to the bailouts specifically: less than $5 \%$ of respondents think that Germany should pay in more, and about $25 \%$ think that the level of contribution should be kept as is. The rest support paying somewhat less (34\%) or a lot less $(33 \%)$. Taken together, these results indicate that financial bailouts are unpopular among German voters. This distribution of responses in our online sample is comparable with those in the main snap polls conducted on this topic and reported in the media. ${ }^{15}$

\section{Economic Self-Interest}

What accounts for the variation in attitudes toward the bailouts? We first evaluate the support for each of the potential channels by which self-interested concerns may affect opposition to the bailouts. Models 1 to 6 in Table 2 report the OLS regression results for our Against Bailout variable, which captures general opposition to the bailouts, and models 7 to 12 report results for the Pay In Less variable, which measures individuals' views on the size of Germany's contribution to the bailout fund. In

${ }^{15}$ According to a ZDF-Politbarometer snap survey conducted in December 2010, 32\% of the German citizens expressed support for financial bailouts of overindebted EU countries versus $62 \%$ that opposed them ("Mehrheit gegen stärkere Finanzhilfen für verschuldete EU-Staaten," Politbarometer Dezember II 2010, 12/17/2010). These results are also similar to those from an Emnid Institute poll conducted in early 2012 (See "Germany Backs Greece Aid, but at a Cost to Merkel," New York Times, 02/27/2012). 


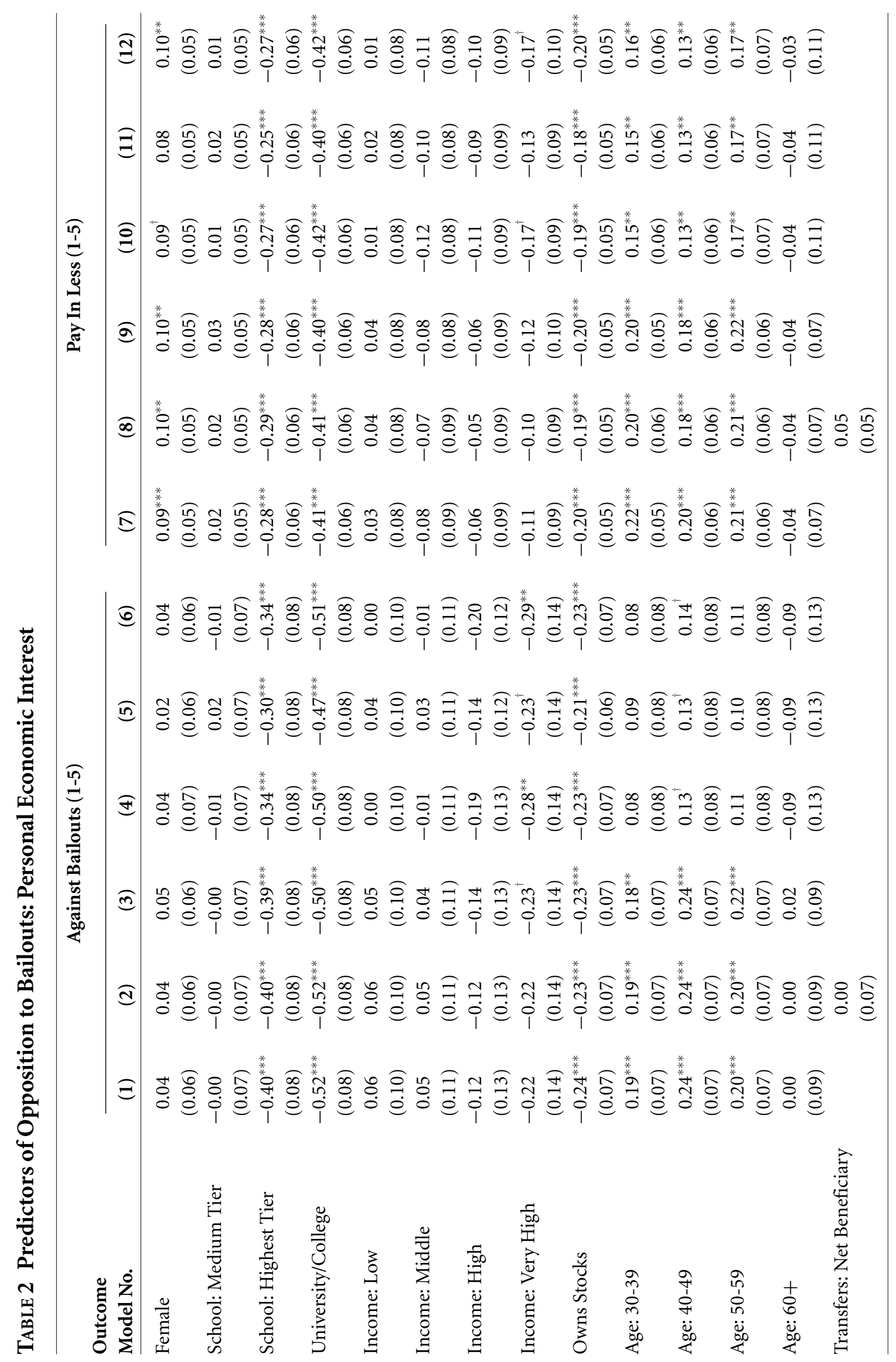




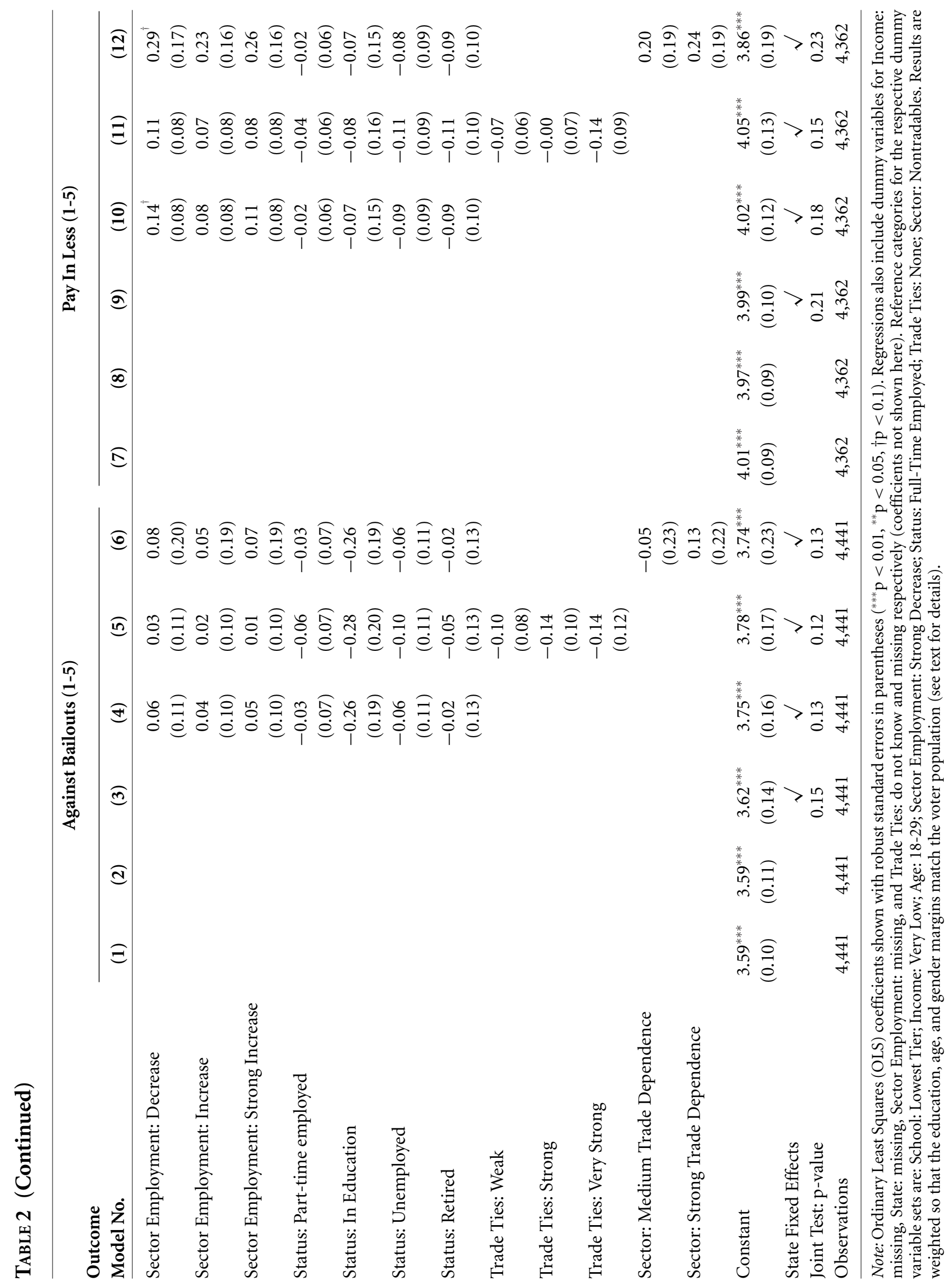


both cases, higher values imply greater opposition. All models control for basic demographics, including education, age, and gender.

We first turn to the income variable. Compared to respondents with very low income (the reference category), very high-income individuals are on average slightly more in favor of the bailouts. This goes against the tax-hike argument, which predicts a negative correlation between income and support for the bailouts. It is also notable that the coefficient on high income is mostly statistically insignificant with regards to the second outcome variable, which measures individuals' opinion about the level of Germany's contribution to the bailout fund (models 7 to 12). Furthermore, as we report below, once we control for measures of social dispositions and political orientations, none of the income measures reaches statistical significance (see Table 3 ). These patterns are clearly inconsistent with the taxation argument.

According to the domestic-spending argument, individuals who currently rely, or expect to depend, on domestic-assistance programs should more strongly oppose the bailouts. The results, however, do not lend much support to this argument. Models 2 and 8 in Table 2 introduce the variable Transfers: Net Beneficiary, which denotes individuals who live in a state that is a net recipient of regional transfers. The variable is statistically insignificant in both models. As another way to assess the potential impact of regional distributional differences, models 3 to 6 and 9 to 12 include state fixed effects. According to the domestic-spending argument, individuals in states like Berlin or Brandenburg, which are net beneficiaries of regional transfers, should oppose financial bailouts more strongly than Baden-Württemberg or Bavaria, states that are among the main net contributors. However, the pvalues from F-tests reported in the bottom panel of Table 2 show that the state fixed effects are jointly insignificant.

The borrowing argument predicts an intergenerational divide over the bailouts, with younger individuals-those likely to bear most of the future costs-expected to oppose the transfers more than older cohorts. The results in Table 2 do reveal some differences in attitudes across age groups, yet we find the strongest opposition to the bailouts among middle-aged individuals. Support for the bailouts is, in fact, higher among the youngest cohort (individuals between 18 and 29, the reference group). This pattern is at odds with the borrowing argument.

Of the mechanisms linking self-interested considerations to attitudes on the bailouts, we only find support for the argument that links financial-asset ownership and support for the bailouts. The results in Table 2 indicate that individuals who own stocks tend to support the bailouts more than individuals who do not. However, the substantive importance of this difference seems limited: only $29 \%$ of the respondents own stocks, and among those who do, the probability of support for the bailout is about 0.2 greater. ${ }^{16}$

To evaluate the employment-security argument, models 4 to 6 and 9 to 12 include measures of the degree of trade dependence of each respondents' industry as well as measures of the overall rate of employment change in the industry. We find that none of the tradedependence variables significantly correlates with attitudes on the bailouts. The same holds for the self-reported Trade Ties measures (models 5 and 11), which are based on respondents' own assessment of how important trade relationships with the EU are for their employer. Working in a declining sector (Employment: Decrease) correlates negatively with opposition to the bailouts, but the variables do not come close to statistical significance once we introduce social and political controls (see left and middle panel in Figure 1). Similarly, respondents' employment status is a weak predictor of bailout attitudes: compared to fully employed individuals (the reference group), the unemployed are not significantly more opposed to the bailouts (models 4-6 and 10-12 in Table 2). In sum, we find little support for the hypothesis that individuals assess the bailouts as a function of their potential impact on their own employment security. ${ }^{17}$

One might argue that bailouts are such a complex issue that only knowledgeable citizens can form a stance that reflects their interests given their own economic standing (Gomez and Wilson 2001). If this is the case, measures of self-interested economic concerns should be significant predictors primarily among the more knowledgeable. To test this conjecture, we replicated the models that capture the relationships between measures of economic self-interest and attitudes on the bailout separately for respondents with high and low levels of political knowledge. Tables S.3 and S.4 in the supporting information present the results. For both outcomes, Against Bailouts and Pay In Less, the predictors capturing economic self-interest (including income, trade dependence, trade ties, and sector-employment changes) are

\footnotetext{
${ }^{16}$ Furthermore, interpreting the correlation between stock ownership and support for the bailout is problematic: when we replicate the model and include interaction terms between income-group indicators and stock ownership, we find that the difference in bailout attitudes is only present among very low-income earners. This appears at odds with the theoretical argument, since poorer individuals tend to hold a much smaller share of stock investments than richer individuals.

${ }^{17}$ Restricting the analysis only to full-time employees does not alter the results statistically or substantively.
} 


\section{FIGURE 1 The Correlates of Preferences for Financial Bailouts}
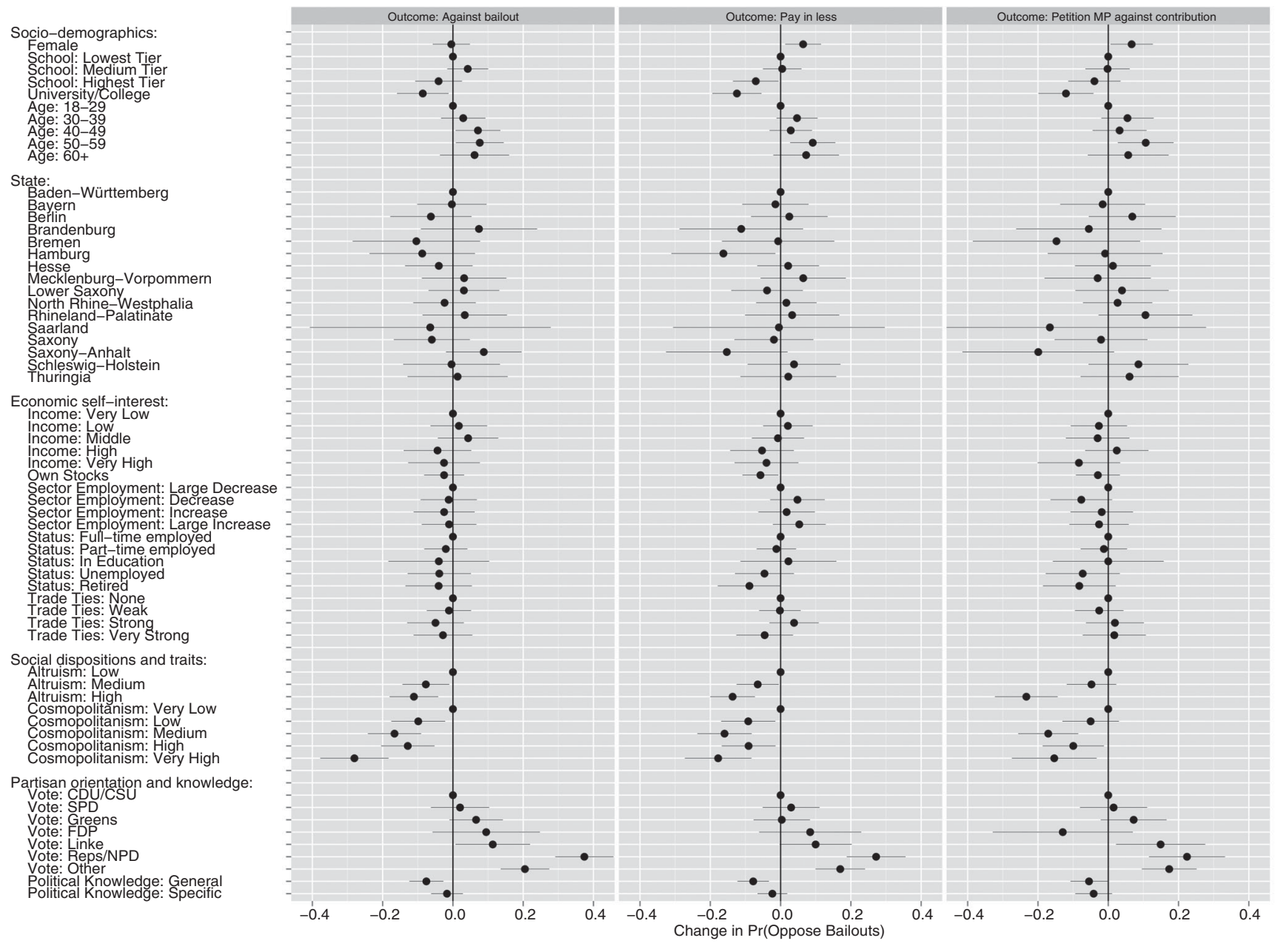

Note: Marginal effects from replications of Model 3 in Table 3 with linear probability models. The outcome variables are: Against bailout ( 1 if a respondent (strongly) opposes bailouts and 0 otherwise); Pay in less ( 1 if a respondent wants Germany to pay in (much) less into the European bailout fund and 0 otherwise); Petition MP against contribution ( 1 if a respondent wants to send an identified message to the MPs saying that Germany should pay in (much) less into the European bailout fund and 0 otherwise (neither, pay in more, pay in much more)). Horizontal lines indicate .95 confidence intervals. The unconditional baseline probabilities and numbers of observations are: Against bailouts $=.57, N=4,350 ;$ Pay in less $=.64, N=4,281 ;$ Petition MP against contribution $=.68, N=2,695$.

statistically insignificant in both subsamples. This suggests that even among individuals who possess more informational resources to detect their economic interests, the self-interest variables fail to significantly predict attitudes toward the bailouts. The only exception is the stock-ownership variable: Here we find that among low-knowledge respondents, those who own stocks are less likely to oppose the bailouts but that among highknowledge respondents, this empirical relationship does not hold. Notably, this pattern is the opposite of what the knowledge-moderated self-interest argument predicts.

Finally, we find that higher levels of education are associated with lower opposition to the bailouts. If education is a proxy for skill, this would be consistent with the employment-security argument, since highly skilled respondents might be more likely to gain economically from bailouts that seek to maintain and support economic openness in the Eurozone. By the same token, less-skilled workers might fear a decrease in their factor returns from bailing out similarly unskilled workers in recipient countries.

To test this channel, we follow previous work (Hainmueller and Hiscox 2006, 2007; Mayda 2008; Scheve and Slaughter 2001a) and conduct split sample tests. If the relationship between skills and opposition towards bailouts stem from self-interested concerns about changes in factor returns, we would expect to find a strong link between skills and attitudes only among respondents who are currently in the labor force, but no such relationship among those who are not. To capture skill levels, 
we follow O'Rourke and Sinnott (2001) and use a more explicit measure of respondents' skill based on the International Labor Organization's ISCO classification scheme that groups specific occupations into four skill categories (see supporting information for coding details).

Table S.5 in the supporting information shows the results for three subsamples: those currently in the labor force, those out of the labor force, and respondents who have retired. In contrast to the expectation, we find no meaningful differences in the relationship between skill levels and opposition to the bailouts. If anything, the negative correlation is stronger among respondents who are out of the labor force or retired, the opposite of what we would expect from a Heckscher-Ohlin logic which posits that those who are currently in paid work should be most concerned about wage and employment-security effects. Taken together, these results suggest that the robust link between skills and attitudes on the bailout is unlikely a reflection of self-interested concerns. Instead, education may be picking up a "residual" of other concepts that are not fully captured by the measures we use (e.g., altruism, cosmopolitanism, knowledge about the crisis).

In sum, then, the results presented so far suggest that attitudes toward the eurozone bailouts do not unfold along distributional lines, as potential domestic winners and losers of the bailout exhibit very similar levels of opposition. To account for the variation in preferences among the broad German public with respect to the bailouts, one must look for additional explanations beyond arguments based on material self-interest.

\section{Social Dispositions and Political Orientation}

The results reported in Table 3 show that altruism, as measured by an individual's chosen donation to charity, strongly correlates with support for the bailouts. Compared to individuals who opted not to donate anything, respondents who either chose to donate between 1 and $50 \%$ of the potential remuneration (Altruism: Medium) as well as voters who chose to donate more than $50 \%$ (Altruism: High) were much more likely to support the bailouts. This finding remains robust for both outcomes when we control for income and the full set of economic controls from the benchmark specification (models 3 and 6 in Table 2).

To facilitate interpreting and comparing the magnitudes of these correlations, the left panel in Figure 1 plots the marginal effects from a linear probability model that regresses opposition to bailouts measured as a binary outcome (coded 1 if a respondent opposes bailouts and 0 otherwise) on all economic, social, and political variables as well as state fixed effects. ${ }^{18}$ As the figure shows, highly altruistic individuals have a .12-points-lower probability of opposing the bailouts than individuals who are not altruistic; this represents a $21 \%$ increase over the baseline probability of opposing the financial transfer of .57. As the middle panel in Figure 1 shows, the magnitude of these results is similar when respondents are asked about whether Germany should pay in more or less into the bailout fund.

Figure 1 also reveals a strong association between cosmopolitanism and attitudes on the bailout. The left panel suggests that individuals with high levels of cosmopolitanism have about a .15-points-lower probability of opposing the bailouts, a drop of about $26 \%$ relative to the mean level of opposition. Among respondents with very high levels of cosmopolitanism, opposition to bailouts is on average about .3 lower than among individuals with low levels of cosmopolitanism, a decrease of about $53 \%$ relative to the baseline probability. Again, results are of a similar magnitude when using the alternative outcome measure (middle panel in Figure 1). Notably, the results on the measures of both altruism and cosmopolitanism remain robust with the inclusion of all the economic controls, education, and state fixed effects.

Models 3 and 6 in Table 3 include a set of political covariates to evaluate the importance of voters' political orientation and political knowledge. The results show that individuals who would vote for the Linke, the most left-wing party in the German parliament, as well as supporters of far-right parties like the NPD and the Republikaner, oppose the financial bailouts significantly more than $C D U$ voters, the governing party whose voters form the reference category. As the left panel in Figure 1 shows, voters of the Linke are on average .1 probability points more likely to oppose the bailouts than voters of the $C D U$. This represents a $17 \%$ increase over the baseline probability of opposing the bailouts. We find an increase twice as large for voters of the right-wing extremist parties. Voters of the liberal FDP, currently the $C D U$ 's minor coalition partner, tend to oppose the bailouts somewhat more than $C D U$ voters, but the difference is not statistically significant at conventional levels. Notably, the level of opposition among voters of the SPD, the major opposition party to the left of the governing coalition, is almost identical to that of CDU voters.

\footnotetext{
${ }^{18} \mathrm{We}$ also reestimated the results using binary and ordered logit regressions. Table S.6 in the supporting information presents the results for the linear probability models and the logit models. As expected, the results from the two models are almost identical. Table S.7 presents the results from the ordered logit, and they are also very similar.
} 
TABle 3 Predictors of Opposition to Bailouts: Social Values and Political Orientation

\begin{tabular}{|c|c|c|c|c|c|c|}
\hline \multirow{2}{*}{$\begin{array}{l}\text { Outcome } \\
\text { Model No. }\end{array}$} & \multicolumn{3}{|c|}{ Against Bailouts (1-5) } & \multicolumn{3}{|c|}{ Pay In Less (1-5) } \\
\hline & $(1)$ & (2) & (3) & (4) & (5) & (6) \\
\hline Altruism: Medium & $\begin{array}{c}-0.25^{* * *} \\
(0.08)\end{array}$ & $\begin{array}{c}-0.21^{* * *} \\
(0.07)\end{array}$ & $\begin{array}{c}-0.21^{* * *} \\
(0.07)\end{array}$ & $\begin{array}{c}-0.17^{* * *} \\
(0.06)\end{array}$ & $\begin{array}{c}-0.14^{* *} \\
(0.06)\end{array}$ & $\begin{array}{c}-0.14^{* *} \\
(0.06)\end{array}$ \\
\hline Altruism: High & $\begin{array}{c}-0.42^{* * *} \\
(0.09)\end{array}$ & $\begin{array}{c}-0.38^{* * *} \\
(0.08)\end{array}$ & $\begin{array}{c}-0.38^{* * *} \\
(0.08)\end{array}$ & $\begin{array}{c}-0.30^{* * *} \\
(0.07)\end{array}$ & $\begin{array}{c}-0.27^{* * *} \\
(0.06)\end{array}$ & $\begin{array}{c}-0.27^{* * *} \\
(0.06)\end{array}$ \\
\hline Cosmopolitanism: Low & $\begin{array}{c}-0.32^{* * *} \\
(0.11)\end{array}$ & $\begin{array}{c}-0.33^{* * *} \\
(0.10)\end{array}$ & $\begin{array}{c}-0.34^{* * *} \\
(0.10)\end{array}$ & $\begin{array}{c}-0.33^{* * *} \\
(0.08)\end{array}$ & $\begin{array}{c}-0.33^{* * *} \\
(0.08)\end{array}$ & $\begin{array}{c}-0.34^{* * *} \\
(0.08)\end{array}$ \\
\hline Cosmopolitanism: Medium & $\begin{array}{c}-0.42^{* * *} \\
(0.11)\end{array}$ & $\begin{array}{c}-0.42^{* * *} \\
(0.10)\end{array}$ & $\begin{array}{c}-0.43^{* * *} \\
(0.10)\end{array}$ & $\begin{array}{c}-0.44^{* * *} \\
(0.08)\end{array}$ & $\begin{array}{c}-0.44^{* * *} \\
(0.08)\end{array}$ & $\begin{array}{c}-0.44^{* * *} \\
(0.08)\end{array}$ \\
\hline Cosmopolitanism: High & $\begin{array}{c}-0.49^{* * *} \\
(0.11)\end{array}$ & $\begin{array}{c}-0.44^{* * *} \\
(0.10)\end{array}$ & $\begin{array}{c}-0.45^{* * *} \\
(0.10)\end{array}$ & $\begin{array}{c}-0.41^{* * *} \\
(0.08)\end{array}$ & $\begin{array}{c}-0.37^{* * *} \\
(0.08)\end{array}$ & $\begin{array}{c}-0.37^{\text {*** }} \\
(0.08)\end{array}$ \\
\hline Cosmopolitanism: Very High & $\begin{array}{c}-0.85^{* * *} \\
(0.13)\end{array}$ & $\begin{array}{c}-0.74^{* * *} \\
(0.13)\end{array}$ & $\begin{array}{c}-0.75^{* * *} \\
(0.13)\end{array}$ & $\begin{array}{c}-0.56^{* * *} \\
(0.09)\end{array}$ & $\begin{array}{c}-0.47^{* * *} \\
(0.09)\end{array}$ & $\begin{array}{c}-0.47^{* * *} \\
(0.09)\end{array}$ \\
\hline Vote: SPD & & $\begin{array}{c}0.05 \\
(0.10)\end{array}$ & $\begin{array}{c}0.06 \\
(0.10)\end{array}$ & & $\begin{array}{c}-0.03 \\
(0.07)\end{array}$ & $\begin{array}{c}-0.01 \\
(0.07)\end{array}$ \\
\hline Vote: Greens & & $\begin{array}{c}0.07 \\
(0.09)\end{array}$ & $\begin{array}{c}0.08 \\
(0.08)\end{array}$ & & $\begin{array}{c}0.01 \\
(0.07)\end{array}$ & $\begin{array}{c}0.01 \\
(0.07)\end{array}$ \\
\hline Vote: FDP & & $\begin{array}{c}0.26^{\dagger} \\
(0.15)\end{array}$ & $\begin{array}{c}0.27^{\dagger} \\
(0.15)\end{array}$ & & $\begin{array}{c}-0.01 \\
(0.13)\end{array}$ & $\begin{array}{c}-0.02 \\
(0.13)\end{array}$ \\
\hline Vote: Linke & & $\begin{array}{l}0.40^{* * *} \\
(0.14)\end{array}$ & $\begin{array}{l}0.41^{* * *} \\
(0.13)\end{array}$ & & $\begin{array}{c}0.20^{\dagger} \\
(0.11)\end{array}$ & $\begin{array}{c}0.21^{\dagger} \\
(0.11)\end{array}$ \\
\hline Vote: NPD/Reps & & $\begin{array}{l}1.01^{* * *} \\
(0.13)\end{array}$ & $\begin{array}{l}1.01^{* * *} \\
(0.12)\end{array}$ & & $\begin{array}{l}0.65^{* * *} \\
(0.09)\end{array}$ & $\begin{array}{l}0.66^{* * *} \\
(0.09)\end{array}$ \\
\hline Vote: Other & & $\begin{array}{l}0.59^{* * *} \\
(0.08)\end{array}$ & $\begin{array}{l}0.58^{* * *} \\
(0.08)\end{array}$ & & $\begin{array}{l}0.38^{* * *} \\
(0.06)\end{array}$ & $\begin{array}{l}0.37^{* * *} \\
(0.06)\end{array}$ \\
\hline Political Knowledge: General & & $\begin{array}{c}-0.20^{\text {*** }} \\
(0.06)\end{array}$ & $\begin{array}{c}-0.20^{* * *} \\
(0.06)\end{array}$ & & $\begin{array}{c}-0.15^{* * *} \\
(0.04)\end{array}$ & $\begin{array}{c}-0.16^{* * *} \\
(0.04)\end{array}$ \\
\hline Political Knowledge: Specific & & $\begin{array}{r}-0.10^{\dagger} \\
(0.05)\end{array}$ & $\begin{array}{c}-0.10^{\dagger} \\
(0.05)\end{array}$ & & $\begin{array}{c}-0.06 \\
(0.04)\end{array}$ & $\begin{array}{c}-0.07 \\
(0.04)\end{array}$ \\
\hline Female & $\begin{array}{c}0.05 \\
(0.06)\end{array}$ & $\begin{array}{c}-0.01 \\
(0.06)\end{array}$ & $\begin{array}{c}-0.02 \\
(0.06)\end{array}$ & $\begin{array}{l}0.10^{* *} \\
(0.05)\end{array}$ & $\begin{array}{c}0.06 \\
(0.04)\end{array}$ & $\begin{array}{c}0.04 \\
(0.05)\end{array}$ \\
\hline School: Medium Tier & $\begin{array}{c}0.04 \\
(0.07)\end{array}$ & $\begin{array}{c}0.09 \\
(0.07)\end{array}$ & $\begin{array}{c}0.08 \\
(0.07)\end{array}$ & $\begin{array}{c}0.04 \\
(0.05)\end{array}$ & $\begin{array}{c}0.06 \\
(0.05)\end{array}$ & $\begin{array}{c}0.05 \\
(0.05)\end{array}$ \\
\hline School: Highest Tier & $\begin{array}{c}-0.28^{* * *} \\
(0.08)\end{array}$ & $\begin{array}{c}-0.13^{\dagger} \\
(0.08)\end{array}$ & $\begin{array}{c}-0.10 \\
(0.08)\end{array}$ & $\begin{array}{c}-0.22^{* * *} \\
(0.06)\end{array}$ & $\begin{array}{c}-0.13^{* *} \\
(0.06)\end{array}$ & $\begin{array}{c}-0.13^{* *} \\
(0.06)\end{array}$ \\
\hline University/College & $\begin{array}{c}-0.36^{\text {*** }} \\
(0.08)\end{array}$ & $\begin{array}{c}-0.22^{* * *} \\
(0.08)\end{array}$ & $\begin{array}{c}-0.23^{* * *} \\
(0.08)\end{array}$ & $\begin{array}{c}-0.33^{* * *} \\
(0.06)\end{array}$ & $\begin{array}{c}-0.24^{* * *} \\
(0.06)\end{array}$ & $\begin{array}{c}-0.26^{\text {*** }} \\
(0.06)\end{array}$ \\
\hline Income: Low & $\begin{array}{c}0.01 \\
(0.09)\end{array}$ & $\begin{array}{c}0.09 \\
(0.09)\end{array}$ & $\begin{array}{c}0.06 \\
(0.09)\end{array}$ & $\begin{array}{c}0.03 \\
(0.08)\end{array}$ & $\begin{array}{c}0.09 \\
(0.07)\end{array}$ & $\begin{array}{c}0.06 \\
(0.07)\end{array}$ \\
\hline Income: Middle & $\begin{array}{c}0.01 \\
(0.10)\end{array}$ & $\begin{array}{c}0.13 \\
(0.10)\end{array}$ & $\begin{array}{c}0.09 \\
(0.10)\end{array}$ & $\begin{array}{c}-0.08 \\
(0.08)\end{array}$ & $\begin{array}{c}-0.00 \\
(0.08)\end{array}$ & $\begin{array}{c}-0.04 \\
(0.07)\end{array}$ \\
\hline Income: High & $\begin{array}{c}-0.14 \\
(0.13)\end{array}$ & $\begin{array}{c}-0.03 \\
(0.11)\end{array}$ & $\begin{array}{c}-0.08 \\
(0.11)\end{array}$ & $\begin{array}{c}-0.05 \\
(0.09)\end{array}$ & $\begin{array}{c}0.02 \\
(0.08)\end{array}$ & $\begin{array}{c}-0.03 \\
(0.08)\end{array}$ \\
\hline Income: Very High & $\begin{array}{c}-0.19 \\
(0.13)\end{array}$ & $\begin{array}{c}-0.04 \\
(0.12)\end{array}$ & $\begin{array}{c}-0.08 \\
(0.12)\end{array}$ & $\begin{array}{c}-0.10 \\
(0.09)\end{array}$ & $\begin{array}{c}-0.00 \\
(0.09)\end{array}$ & $\begin{array}{c}-0.03 \\
(0.08)\end{array}$ \\
\hline Owns Stocks & $\begin{array}{c}-0.18^{* * *} \\
(0.06)\end{array}$ & $\begin{array}{c}-0.12^{* *} \\
(0.06)\end{array}$ & $\begin{array}{c}-0.12^{\dagger} \\
(0.06)\end{array}$ & $\begin{array}{c}-0.17^{* * *} \\
(0.05)\end{array}$ & $\begin{array}{c}-0.13^{* * *} \\
(0.05)\end{array}$ & $\begin{array}{c}-0.12^{* * *} \\
(0.05)\end{array}$ \\
\hline
\end{tabular}


TABLE 3 (Continued)

\begin{tabular}{|c|c|c|c|c|c|c|}
\hline \multirow{2}{*}{$\begin{array}{l}\text { Outcome } \\
\text { Model No. }\end{array}$} & \multicolumn{3}{|c|}{ Against Bailouts (1-5) } & \multicolumn{3}{|c|}{ Pay In Less (1-5) } \\
\hline & (1) & (2) & (3) & (4) & (5) & (6) \\
\hline Age: $30-39$ & $\begin{array}{l}0.14^{* *} \\
(0.07)\end{array}$ & $\begin{array}{c}0.11 \\
(0.07)\end{array}$ & $\begin{array}{c}0.04 \\
(0.08)\end{array}$ & $\begin{array}{l}0.20^{* * *} \\
(0.06)\end{array}$ & $\begin{array}{l}0.17^{* * *} \\
(0.05)\end{array}$ & $\begin{array}{l}0.15^{* *} \\
(0.06)\end{array}$ \\
\hline Age: $40-49$ & $\begin{array}{l}0.25^{* * *} \\
(0.07)\end{array}$ & $\begin{array}{l}0.23^{* * *} \\
(0.07)\end{array}$ & $\begin{array}{c}0.15^{* *} \\
(0.08)\end{array}$ & $\begin{array}{l}0.20^{* * *} \\
(0.06)\end{array}$ & $\begin{array}{l}0.18^{* * *} \\
(0.06)\end{array}$ & $\begin{array}{c}0.16^{* *} \\
(0.06)\end{array}$ \\
\hline Age: $50-59$ & $\begin{array}{l}0.22^{* * *} \\
(0.07)\end{array}$ & $\begin{array}{l}0.24^{* * *} \\
(0.07)\end{array}$ & $\begin{array}{c}0.15^{\dagger} \\
(0.08)\end{array}$ & $\begin{array}{l}0.23^{* * *} \\
(0.06)\end{array}$ & $\begin{array}{l}0.25^{* * *} \\
(0.06)\end{array}$ & $\begin{array}{l}0.23^{* * *} \\
(0.06)\end{array}$ \\
\hline Age: $60+$ & $\begin{array}{c}0.09 \\
(0.09)\end{array}$ & $\begin{array}{c}0.14^{\dagger} \\
(0.08)\end{array}$ & $\begin{array}{c}0.09 \\
(0.12)\end{array}$ & $\begin{array}{c}0.03 \\
(0.07)\end{array}$ & $\begin{array}{c}0.06 \\
(0.06)\end{array}$ & $\begin{array}{c}0.10 \\
(0.10)\end{array}$ \\
\hline Constant & $\begin{array}{l}4.08^{* * *} \\
(0.16)\end{array}$ & $\begin{array}{l}3.75^{* * *} \\
(0.17)\end{array}$ & $\begin{array}{l}3.91^{* * *} \\
(0.19)\end{array}$ & $\begin{array}{l}4.40^{* * *} \\
(0.12)\end{array}$ & $\begin{array}{l}4.22^{* * *} \\
(0.13)\end{array}$ & $\begin{array}{l}4.26^{\text {*** }} \\
(0.14)\end{array}$ \\
\hline Other Economic Controls & & & $\sqrt{ }$ & & & $\sqrt{ }$ \\
\hline State Fixed Effects & $\sqrt{ }$ & $\sqrt{ }$ & $\sqrt{ }$ & $\sqrt{ }$ & $\sqrt{ }$ & $\sqrt{ }$ \\
\hline Observations & 4,350 & 4,350 & 4,350 & 4,281 & 4,281 & 4,281 \\
\hline
\end{tabular}

Note: Ordinary Least Squares (OLS) coefficients shown with robust standard errors in parentheses $\left({ }^{* * *} \mathrm{p}<0.01,{ }^{* *} \mathrm{p}<0.05, \dagger \mathrm{p}<0.1\right)$. All regressions include state fixed effects and models 3 and 6 also include our full set of economic controls as in model 6, Table 2 (including employment status, trade dependence, and sector-employment change). Regressions also include dummy variables for Income: missing, and State: Missing, respectively (coefficients not shown here). Reference categories for the respective dummy variable sets are: Cosmopolitanism: Very low; Vote: CDU; School: Lowest Tier; Income: Very Low; Age: 18-29. Results are weighted so that the education, age, and gender margins match the voter population (see text for details).

These results suggest that partisan orientation correlates quite strongly with respondents' preferences for bailout policies. At the same time, the results also show that the differences in partisan preferences do not map onto a traditional left-right divide. Rather, we find that voters located on the two extremes of the ideological spectrum are significantly more opposed to the financial rescues than the voters of centrist parties. This result is consistent with previous work that documented an inverted U-shaped relationship between parties' positions on the left-right dimension and support for European integration (Hooghe, Marks, and Wilson 2002).

How should one interpret the strong association between partisan orientation and attitudes on the bailouts? One possibility is that less-knowledgeable individuals rely more on partisan cues when forming political opinions, since such cues allow them to economize on the costs of acquiring knowledge on complex issues (Downs 1957). Alternatively, others have argued that capitalizing on cues itself requires a certain degree of political knowledge (Zaller 1991). Whereas the former approach predicts a stronger effect of party cues on the less knowledgeable, the second approach predicts the exact opposite.

To evaluate these two claims, Table 4 breaks down the results by respondents' levels of knowledge. We focus on two types of knowledge: possessing general political information and issue-specific knowledge pertaining directly to the financial crisis. Models 1 to 4 show the results for attitudes toward the bailouts, and models 5 to 8 report results for individual opposition to Germany contributing more into the European bailout fund. The results show that the relationship between partisan orientation and opposition to the bailouts is mostly stronger among more knowledgeable individuals. For example, the coefficient is 0.7 for extreme-right voters (NPD and Republikaner) who possess a low degree of general political knowledge (model 1 in Table 4), but about 1.3 for their more informed counterparts (model 2). We observe similar patterns for voters of the liberal party $(F D P)$. These results are consistent with Zaller's argument that only more knowledgeable individuals possess the informational resources necessary for capitalizing on partisan cues. However, the congruence in views about the bailouts between parties and their voters might also reflect that voters are expressing support for a given party because of its position on the issue.

\section{Robustness and External Validity}

In this section, we evaluate both the robustness of our results and the extent to which they generalize to the German voter population. 
TABLE 4 Predictors of Opposition to Bailouts: Political Knowledge

Outcome

Sample:

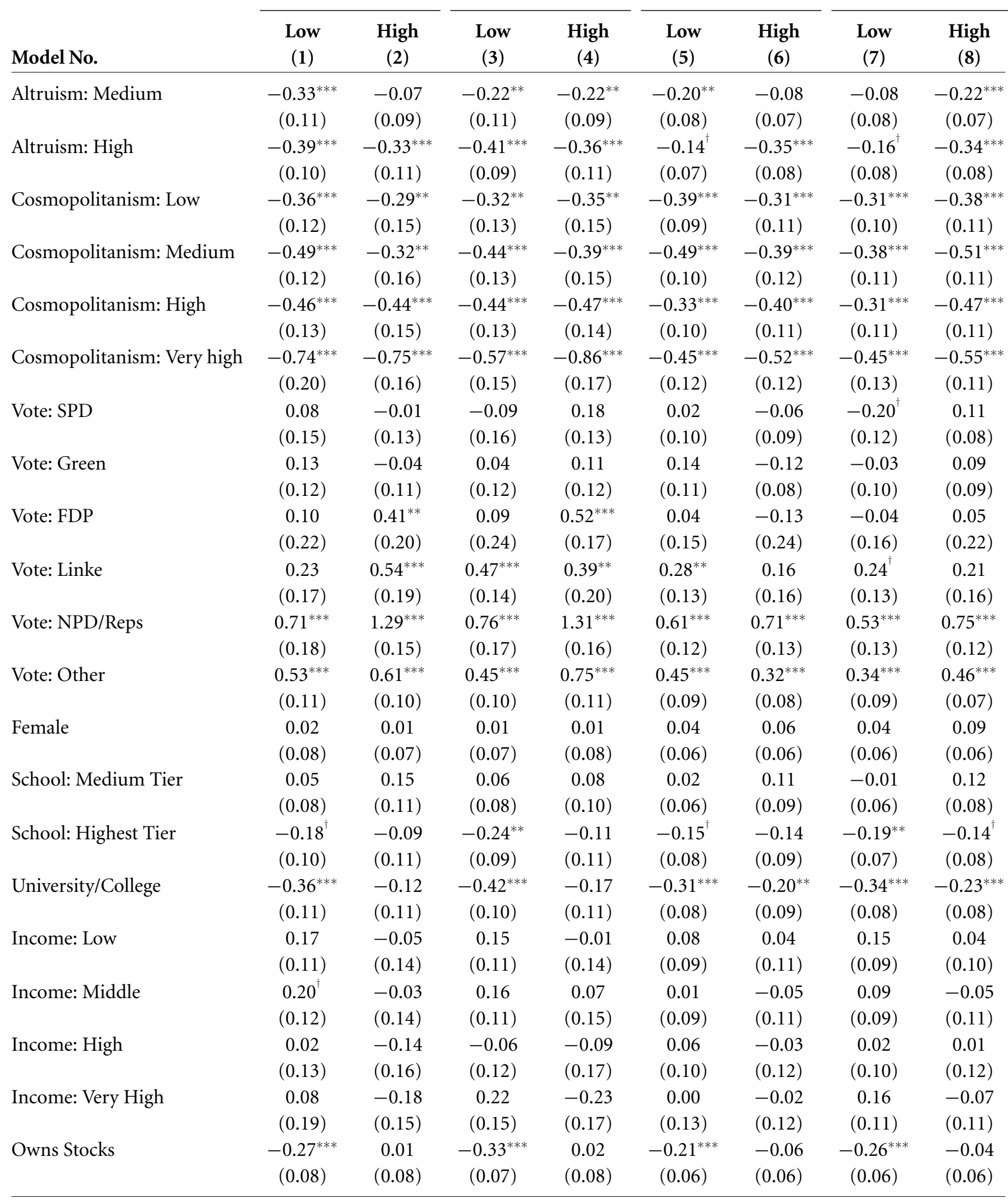

Against Bailouts (1-5)

Pay In Less (1-5)
General Knowledge Specific Knowledge

igh

\begin{tabular}{|c|c|c|c|}
\hline General Knowledge & Specific Knowledge & General Knowledge & Specific Knowledge \\
\hline High & High & High & High \\
\hline
\end{tabular}


TABLE 4 (Continued)

\begin{tabular}{|c|c|c|c|c|c|c|c|c|}
\hline \multirow{3}{*}{$\begin{array}{l}\text { Outcome } \\
\text { Sample: } \\
\text { Model No. }\end{array}$} & \multicolumn{4}{|c|}{ Against Bailouts (1-5) } & \multicolumn{4}{|c|}{ Pay In Less (1-5) } \\
\hline & \multicolumn{2}{|c|}{ General Knowledge } & \multicolumn{2}{|c|}{ Specific Knowledge } & \multicolumn{2}{|c|}{ General Knowledge } & \multicolumn{2}{|c|}{ Specific Knowledge } \\
\hline & $\begin{array}{l}\text { Low } \\
(1)\end{array}$ & $\begin{array}{l}\text { High } \\
(2)\end{array}$ & $\begin{array}{l}\text { Low } \\
(3)\end{array}$ & $\begin{array}{l}\text { High } \\
(4)\end{array}$ & $\begin{array}{l}\text { Low } \\
(5)\end{array}$ & $\begin{array}{l}\text { High } \\
(6)\end{array}$ & $\begin{array}{l}\text { Low } \\
(7)\end{array}$ & $\begin{array}{l}\text { High } \\
(8)\end{array}$ \\
\hline Age: $30-39$ & $\begin{array}{l}0.21^{* *} \\
(0.10)\end{array}$ & $\begin{array}{c}0.02 \\
(0.09)\end{array}$ & $\begin{array}{l}0.18^{\dagger} \\
(0.10)\end{array}$ & $\begin{array}{c}0.04 \\
(0.09)\end{array}$ & $\begin{array}{c}0.26^{* * *} \\
(0.08)\end{array}$ & $\begin{array}{c}0.09 \\
(0.07)\end{array}$ & $\begin{array}{c}0.25^{* * *} \\
(0.08)\end{array}$ & $\begin{array}{c}0.11 \\
(0.07)\end{array}$ \\
\hline Age: $40-49$ & $\begin{array}{l}0.23^{* *} \\
(0.10)\end{array}$ & $\begin{array}{l}0.26^{* * *} \\
(0.09)\end{array}$ & $\begin{array}{l}0.24^{* *} \\
(0.10)\end{array}$ & $\begin{array}{l}0.23^{* *} \\
(0.09)\end{array}$ & $\begin{array}{c}0.25^{* * *} \\
(0.08)\end{array}$ & $\begin{array}{l}0.13^{\dagger} \\
(0.07)\end{array}$ & $\begin{array}{l}0.26^{* * *} \\
(0.08)\end{array}$ & $\begin{array}{l}0.11 \\
(0.07)\end{array}$ \\
\hline Age: $50-59$ & $\begin{array}{l}0.27^{* * *} \\
(0.10)\end{array}$ & $\begin{array}{l}0.23^{* *} \\
(0.10)\end{array}$ & $\begin{array}{l}0.23^{* *} \\
(0.11)\end{array}$ & $\begin{array}{l}0.24^{* *} \\
(0.10)\end{array}$ & $\begin{array}{c}0.33^{* * *} \\
(0.08)\end{array}$ & $\begin{array}{l}0.16^{* *} \\
(0.08)\end{array}$ & $\begin{array}{l}0.29^{* * *} \\
(0.08)\end{array}$ & $\begin{array}{r}0.19^{* * *} \\
(0.07)\end{array}$ \\
\hline Age: $60+$ & $\begin{array}{l}0.24^{* *} \\
(0.12)\end{array}$ & $\begin{array}{c}0.01 \\
(0.11)\end{array}$ & $\begin{array}{c}0.18 \\
(0.13)\end{array}$ & $\begin{array}{c}0.12 \\
(0.11)\end{array}$ & $\begin{array}{l}0.22^{* *} \\
(0.09)\end{array}$ & $\begin{array}{l}-0.14 \\
(0.09)\end{array}$ & $\begin{array}{c}0.14 \\
(0.10)\end{array}$ & $\begin{array}{l}-0.01 \\
(0.08)\end{array}$ \\
\hline Constant & $\begin{array}{l}3.66^{* * *} \\
(0.22)\end{array}$ & $\begin{array}{l}3.56^{* * *} \\
(0.24)\end{array}$ & $\begin{array}{c}3.75^{* * *} \\
(0.21)\end{array}$ & $\begin{array}{c}3.51^{* * *} \\
(0.24)\end{array}$ & $\begin{array}{c}3.97^{* * *} \\
(0.16)\end{array}$ & $\begin{array}{l}4.27^{* * *} \\
(0.18)\end{array}$ & $\begin{array}{l}4.05^{* * *} \\
(0.17)\end{array}$ & $\begin{array}{r}4.17^{* * *} \\
(0.17)\end{array}$ \\
\hline $\begin{array}{l}\text { State Fixed Effects } \\
\text { Observations }\end{array}$ & $\begin{array}{c}\sqrt{ } \\
1,906\end{array}$ & $\begin{array}{c}\sqrt{ } \\
2,444\end{array}$ & $\begin{array}{c}\sqrt{ } \\
1,917\end{array}$ & $\begin{array}{c}\sqrt{ } \\
2,433\end{array}$ & $\begin{array}{c}\sqrt{ } \\
1,861\end{array}$ & $\begin{array}{c}\sqrt{ } \\
2,420\end{array}$ & $\begin{array}{c}\sqrt{ } \\
1,879\end{array}$ & $\begin{array}{c}\sqrt{ } \\
2,402\end{array}$ \\
\hline
\end{tabular}

Note: Ordinary Least Squares (OLS) coefficients shown with robust standard errors in parentheses $\left({ }^{* * *} \mathrm{p}<0.01,{ }^{* *} \mathrm{p}<0.05, \dagger \mathrm{p}<0.1\right)$. Models 1 and 2 and 5 and 6 use the subsample of respondents with low and high general political knowledge respectively; Models 3 \& 4 and $7 \& 8$ use the subsample of respondents with low and high specific political knowledge, respectively. All regressions include state fixed effects. Regressions also include dummy variables for Income: missing, and State: Missing, respectively (coefficients not shown here). Reference categories for the respective dummy variable sets are: Cosmopolitanism: Very low; Vote: CDU; School: Lowest Tier; Income: Very Low; Age: 18-29. Results are weighted so that the education, age, and gender margins match the voter population (see text for details).

\section{Quasi-Behavioral Measure of Bailout Preferences}

We first evaluate if the results from the relatively "costless" attitudinal measures remain intact once we increase the stakes somewhat by providing respondents with an opportunity to sign up for sending a message regarding their position on the bailout to their legislators (for a similar strategy, see Hainmueller, Hiscox, and Margalit (2013)). Respondents are notified that this message will include some basic personal information. The question wording is:

"Currently there is much discussion about whether Germany should pay more or less money into the European financial rescue package, which is used to help over-indebted EU countries. Should we inform the Members of Parliament on your behalf whether you want Germany to pay somewhat more or somewhat less into the European financial rescue fund? This information notice would contain your name and residence location."

Answer categories included: "no, please do not send a notice to the MPs" or "please inform the MPs on my behalf that Germany should pay a lot less/somewhat less/neither less nor more/somewhat more/a lot more money into the European financial rescue fund."

About $65 \%$ of the respondents signed up to send a message to their MPs. Among those who signed up, almost $71 \%$ asked to send a message to their MP calling for Germany to contribute either less or much less. Twentyfour Percent support keeping the amount at the current level, and only $5 \%$ signed up to send a message calling for Germany to pay in more.

We reestimated all the models reported above using this quasi-behavioral outcome measure and report the main results in Table 5. The findings again suggest that social values and political orientation are strong predictors of attitudes toward the financial bailouts while personal economic factors perform relatively poorly. Models 1 and 2 in Table 5 indicates that stock ownership correlates negatively with opposition to greater contributions to the bailouts, but the coefficient drops insignificant in the fully specified model (model 3 ) which includes state fixed effects as well as economic and sociodemographic controls. As before, the finding that individuals close to retirement age (50 to 59 years) oppose the bailouts more strongly than younger citizens goes against the logic of the borrowing argument. 


\section{TABLE 5 Predictors of Opposition to Bailouts: Social Values and Political Orientation (quasi-behavioral measure)}

\begin{tabular}{|c|c|c|c|}
\hline \multirow{2}{*}{$\begin{array}{l}\text { Outcome } \\
\text { Model No. }\end{array}$} & \multicolumn{3}{|c|}{$\begin{array}{l}\text { Petition MP against } \\
\text { contribution (1-5) }\end{array}$} \\
\hline & (1) & (2) & (3) \\
\hline Altruism: Medium & $\begin{array}{l}-0.14^{\dagger} \\
(0.07)\end{array}$ & $\begin{array}{l}-0.12^{\dagger} \\
(0.07)\end{array}$ & $\begin{array}{l}-0.12 \\
(0.07)\end{array}$ \\
\hline Altruism: High & $\begin{array}{c}-0.45^{* * *} \\
(0.11)\end{array}$ & $\begin{array}{c}-0.41^{* * *} \\
(0.10)\end{array}$ & $\begin{array}{c}-0.42^{* * *} \\
(0.10)\end{array}$ \\
\hline Cosmopolitanism: Low & $\begin{array}{c}-0.25^{* * *} \\
(0.10)\end{array}$ & $\begin{array}{c}-0.25^{* * *} \\
(0.09)\end{array}$ & $\begin{array}{c}-0.24^{* * *} \\
(0.09)\end{array}$ \\
\hline Cosmopolitanism: Medium & $\begin{array}{c}-0.43^{* * *} \\
(0.10)\end{array}$ & $\begin{array}{c}-0.41^{* * *} \\
(0.10)\end{array}$ & $\begin{array}{c}-0.40^{* * *} \\
(0.09)\end{array}$ \\
\hline Cosmopolitanism: High & $\begin{array}{c}-0.39^{* * *} \\
(0.10)\end{array}$ & $\begin{array}{c}-0.35^{* * *} \\
(0.10)\end{array}$ & $\begin{array}{c}-0.34^{* * *} \\
(0.10)\end{array}$ \\
\hline Cosmopolitanism: Very High & $\begin{array}{c}-0.42^{* * *} \\
(0.13)\end{array}$ & $\begin{array}{c}-0.34^{* * *} \\
(0.13)\end{array}$ & $\begin{array}{c}-0.34^{* * *} \\
(0.12)\end{array}$ \\
\hline Vote: SPD & & $\begin{array}{l}-0.04 \\
(0.09)\end{array}$ & $\begin{array}{l}-0.04 \\
(0.09)\end{array}$ \\
\hline Vote: Greens & & $\begin{array}{c}0.04 \\
(0.08)\end{array}$ & $\begin{array}{c}0.05 \\
(0.08)\end{array}$ \\
\hline Vote: FDP & & $\begin{array}{l}-0.29^{\dagger} \\
(0.16)\end{array}$ & $\begin{array}{l}-0.31^{\dagger} \\
(0.16)\end{array}$ \\
\hline Vote: Linke & & $\begin{array}{l}0.31^{* *} \\
(0.14)\end{array}$ & $\begin{array}{l}0.30^{* *} \\
(0.14)\end{array}$ \\
\hline Vote: NPD/Reps & & $\begin{array}{l}0.59^{* * *} \\
(0.11)\end{array}$ & $\begin{array}{l}0.59^{* * *} \\
(0.11)\end{array}$ \\
\hline Vote: Other & & $\begin{array}{l}0.40^{* * *} \\
(0.08)\end{array}$ & $\begin{array}{l}0.39^{* * *} \\
(0.08)\end{array}$ \\
\hline Political Knowledge: General & & $\begin{array}{c}-0.11^{* *} \\
(0.06)\end{array}$ & $\begin{array}{c}-0.13^{* *} \\
(0.05)\end{array}$ \\
\hline Political Knowledge: Specific & & $\begin{array}{l}-0.04 \\
(0.05)\end{array}$ & $\begin{array}{l}-0.03 \\
(0.05)\end{array}$ \\
\hline Female & $\begin{array}{c}0.09 \\
(0.06)\end{array}$ & $\begin{array}{c}0.07 \\
(0.06)\end{array}$ & $\begin{array}{c}0.08 \\
(0.06)\end{array}$ \\
\hline School: Medium Tier & $\begin{array}{l}-0.01 \\
(0.06)\end{array}$ & $\begin{array}{l}-0.01 \\
(0.06)\end{array}$ & $\begin{array}{l}-0.02 \\
(0.06)\end{array}$ \\
\hline School: Highest Tier & $\begin{array}{c}-0.21^{* * *} \\
(0.08)\end{array}$ & $\begin{array}{c}-0.15^{* *} \\
(0.08)\end{array}$ & $\begin{array}{l}-0.15^{\dagger} \\
(0.08)\end{array}$ \\
\hline University/College & $\begin{array}{c}-0.37^{* * *} \\
(0.08)\end{array}$ & $\begin{array}{c}-0.31^{* * *} \\
(0.08)\end{array}$ & $\begin{array}{c}-0.34^{* * *} \\
(0.08)\end{array}$ \\
\hline Income: Low & $\begin{array}{c}0.01 \\
(0.09)\end{array}$ & $\begin{array}{c}0.06 \\
(0.09)\end{array}$ & $\begin{array}{c}0.04 \\
(0.09)\end{array}$ \\
\hline Income: Middle & $\begin{array}{l}-0.02 \\
(0.11)\end{array}$ & $\begin{array}{c}0.06 \\
(0.10)\end{array}$ & $\begin{array}{c}0.02 \\
(0.10)\end{array}$ \\
\hline Income: High & $\begin{array}{c}0.14 \\
(0.11)\end{array}$ & $\begin{array}{l}0.20^{* *} \\
(0.10)\end{array}$ & $\begin{array}{c}0.16 \\
(0.10)\end{array}$ \\
\hline
\end{tabular}

(Continued)
TABle 5 (Continued)

\begin{tabular}{lccc}
\hline & \multicolumn{3}{c}{$\begin{array}{c}\text { Petition MP against } \\
\text { contribution (1-5) }\end{array}$} \\
\cline { 2 - 4 } Outcome & $(\mathbf{1})$ & $(2)$ & $(3)$ \\
Model No. & 0.00 & 0.11 & 0.06 \\
\hline Income: Very High & $(0.13)$ & $(0.12)$ & $(0.12)$ \\
& $-0.15^{* *}$ & $-0.10^{\dagger}$ & -0.09 \\
Owns Stocks & $(0.06)$ & $(0.06)$ & $(0.06)$ \\
& $0.15^{\dagger}$ & $0.12^{\dagger}$ & 0.10 \\
Age: 30-39 & $(0.07)$ & $(0.07)$ & $(0.08)$ \\
& $0.16^{* *}$ & $0.13^{\dagger}$ & 0.12 \\
Age: $40-49$ & $(0.08)$ & $(0.07)$ & $(0.08)$ \\
& $0.29^{* * *}$ & $0.28^{* * *}$ & $0.29^{* * *}$ \\
Age: $50-59$ & $(0.08)$ & $(0.08)$ & $(0.09)$ \\
& -0.00 & 0.03 & 0.17 \\
Age: 60+ & $(0.09)$ & $(0.08)$ & $(0.13)$ \\
& $4.35^{* * *}$ & $4.15^{* * *}$ & $4.18^{* * *}$ \\
Constant & $(0.14)$ & $(0.15)$ & $(0.19)$ \\
& & & $\sqrt{ }$ \\
Other Economic Controls & $\sqrt{ }$ & $\sqrt{ }$ & $\sqrt{ }$ \\
State Fixed Effects & 2,695 & 2,695 & 2,695 \\
Observations & & & \\
\hline
\end{tabular}

Note: Ordinary Least Squares (OLS) coefficients shown with robust standard errors in parentheses $\left({ }^{* * *} \mathrm{p}<0.01,{ }^{* *} \mathrm{p}<0.05, \dagger \mathrm{p}<0.1\right)$. All regressions include state fixed effects and model 3 also includes our full set of economic controls as in model 6, Table 2 (including employment status, trade dependence, and sector employment change). Regressions also include dummy variables for Income: missing, and State: missing, respectively (coefficients not shown here). Reference categories for the respective dummy variable sets are: Cosmopolitanism: Very low; Vote: CDU; School: Lowest Tier; Income: Very Low; Age: 18-29. Results are weighted so that the education, age, and gender margins match the voter population (see text for details).

The analysis of the quasi-behavioral measure again reveals the strong association between social dispositions and support for the bailout. More altruistic individuals, as well as those with a higher level of cosmopolitanism, are significantly less likely to sign up for sending a message to their legislator opposing Germany's contribution to the bailout. To ease the interpretation of the effects, the right panel in Figure 1 displays the results graphically.

The findings are similar to those obtained with the attitudinal outcome variables. In the supporting information, we show that the same is true when we use the quasi-behavioral measure and replicate our tests for the different personal economic measures using the complete sample (Table S.8), a separate analysis among highand low-information respondents (Table S.9), as well as knowledge-moderated tests for the partisan orientations (Table S.10). Taken together, these additional tests show that the original results remain robust when testing a 
range of different specifications against both attitudinal and quasi-behavioral outcome measures.

\section{External Validity}

To explore whether our findings from the online survey generalize to the voter population, we included both questions about attitudes towards the bailouts in a phone survey that was carried out by a different polling firm and recruited respondents via random-digit dialing. Table S.11 in the supporting information compares the responses obtained in the phone and online sample (both samples are weighted to match the education, age, and gender margins of the voter population).

The answer distributions are comparable across the two samples, although in the online sample, respondents were more strongly opposed to the bailouts and somewhat less likely to select the neutral category ("neither in favor nor against"). To examine whether the results we obtained from analyzing the online survey generalize to the telephone sample, we regress support for bailouts on all sociodemographic and economic variables that are available in both surveys and a full set of interactions of all predictors with a dummy variable that indicates whether the survey was carried out online or by phone. The interaction terms assess whether the online results significantly differ from those obtained in the telephone sample. ${ }^{19}$

Table S.12 in the supporting information reports the results. Even without controls for any of the social and political factors, we find limited support for the predictions based on an economic self-interest perspective in both samples. Furthermore, the p-values from F-tests reported in the last row of the table reveal that the interaction terms are jointly insignificant, which indicates that the coefficients from the online survey do not significantly differ from those obtained in the telephone survey. ${ }^{20} \mathrm{In}$ sum, this analysis of the external validity of the online results suggests that interview mode does not account for significant aspects of the results we obtained.

\footnotetext{
${ }^{19}$ We lack several important measures of social dispositions and partisan affiliation, as budget constraints precluded introducing all these items in the telephone survey. Nevertheless, the analysis still enables us to explore whether the findings replicate for standard economic variables such as income or employment using the telephone sample.

${ }^{20}$ The only two exceptions are the interaction between the variables Age: 50-59 and Phone survey mode in models 3 and 4 and the interaction between Phone and High School: Medium Tier in model 3 . The negative signs of the corresponding coefficients suggest that respondents in these categories are less opposed to Germany's contribution to the bailouts when interviewed in the telephone than in the online model.
}

\section{Bailout Preferences and Sociotropic Economic Concerns: Experimental Findings}

Although economic self-interest does not appear to be a significant predictor of attitudes toward financial bailouts, voters might oppose these transfers based on sociotropic concerns, such as how burdensome they perceive the bailout contributions to be on the German economy as a whole. To the extent that this sensitivity does exist, it provides us with a useful opportunity to further explore whether economic self-interest matters: the taxhike and the domestic spending argument predict that both individuals with low income and high income will be more averse to increases in Germany's contribution than middle-income earners; those with low incomes are expected to be concerned about cuts in domestic spending and those with high incomes about future tax increases policy makers may levy to finance the bailouts.

To answer this question, we embedded an experimental item in the survey. The question we asked respondents was how likely they were to vote in favor or against a specific bailout package in a referendum-like vote (answers ranged on a 7-point scale from "vote definitely against" to "vote definitely in favor"). The experimental component was a manipulation in which we randomly varied what respondents were told would be the size of Germany's contribution to the bailout fund ( $€ 123$, €189, $€ 211$, or $€ 418$, respectively). The random assignment of the reported value in combination with a large sample ensures that we can compare the levels of opposition to the bailouts across the experimental groups with the results having a causal interpretation.

First, we examine whether the size of Germany's contribution to the bailout fund affects voters' willingness to support the proposal. Figure 2 plots the results from a linear probability model that regresses a binary indicator for opposition to the bailouts (coded 1 if a respondent disapproves of the bailouts and zero otherwise) on dummy variables for the experimental groups. We first consider the results for all respondents, which are displayed at the top of Figure 2. The graph indicates that opposition to the bailouts indeed varies significantly as a function of the size of Germany's contribution. As the contribution rises from $€ 123 \mathrm{bn}$, the reference category, to $€ 189 \mathrm{bn}$, the probability of opposing the bailout increases by about .03 points. Since the average baseline probability of opposing the bailout is .46 , this effect represents a shift of about $7 \%$ over the mean level of opposition. If the size of the contribution increases to $€ 211 \mathrm{bn}$, which is the amount Germany has agreed to contribute, the probability of 


\section{FIGURE 2 The Effects of Increases in the Size of Contributions to Financial Bailouts: Experimental Results by Income Groups}

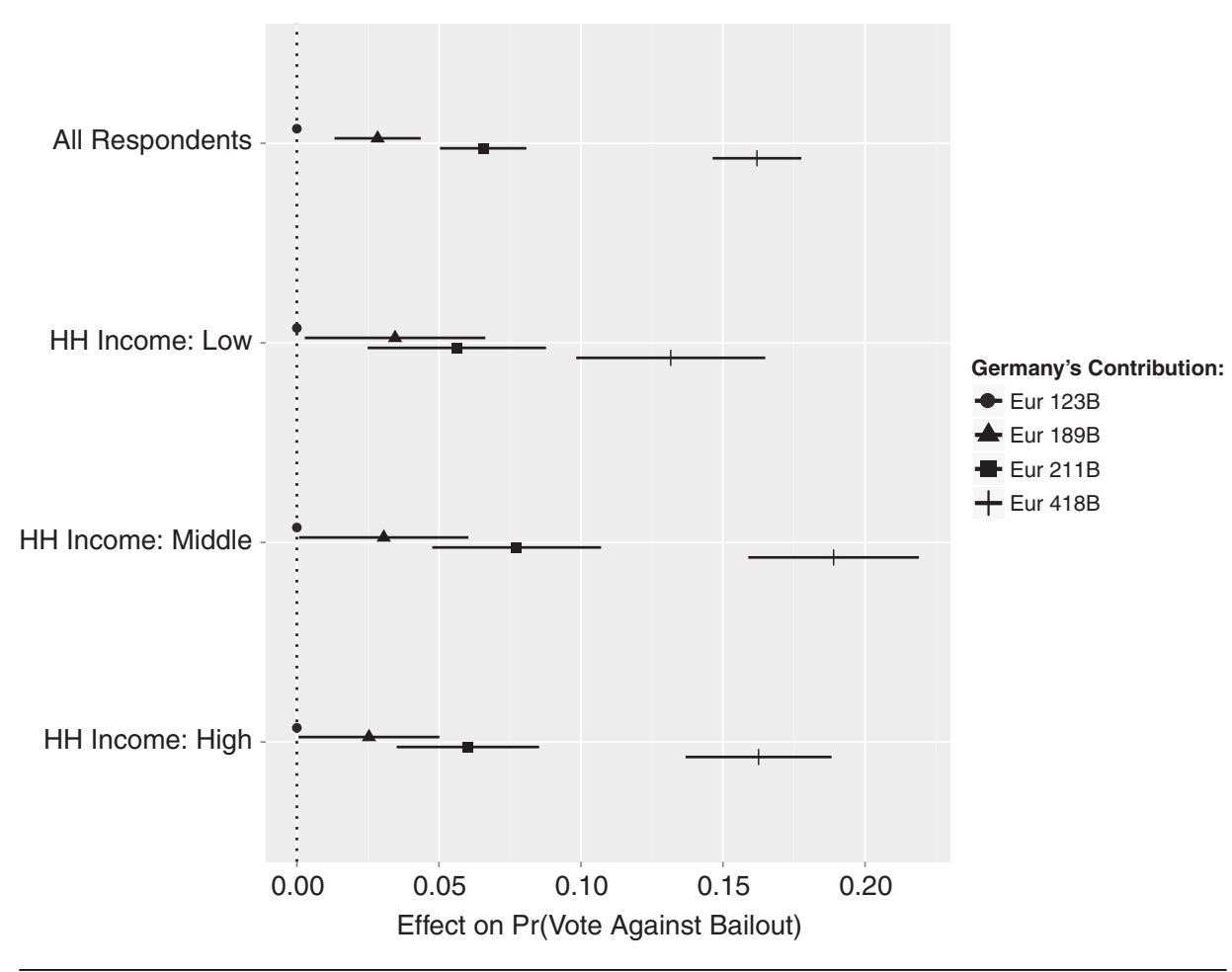

Note: The figure shows marginal effects from a linear probability model with robust standard errors. The dependent variable, opposition to bailouts, is a binary indicator variable which equals 1 if a respondent (strongly) disapproves of bailouts and is 0 otherwise (neither, somewhat approve, and strongly approve). Horizontal lines indicate .95 confidence intervals. The unconditional baseline probabilities are: all $=0.46$, high income $=0.45$, middle income $=0.46$, low income $=0.46$. Respondents: $N=4,364$.

opposing the bailout rises by about .06 points, which equals a $13 \%$ increase relative to the baseline probability. Finally, in the group assigned the highest contribution ( $€ 418 \mathrm{bn}$ ), opposition to the bailout is on average 0.16 points greater, a whopping $34 \%$ increase in the probability of opposition relative to the baseline probability. ${ }^{21}$ These results indicate that voters assign great significance to the economic costs of the bailout, a finding that appears consistent with a sociotropic concern about the financial burden placed on the country's economy.

Next, we examine whether voters with different economic interests, as measured by their income level, exhibit different degrees of concern about the economic costs of the bailout. If self-interested concerns underlie the sensitivity to the size of Germany's contribution to the bailout, one would expect that individuals with higher incomes, those likely to shoulder a larger share of the cost through

\footnotetext{
${ }^{21}$ The German government has indeed recently considered increasing Germany's contribution up to $€ 500$ bn (see: "Merkel erwägt nun doch grösseren Rettungsschirm," Der Spiegel, 03/01/2012).
}

a progressive tax system, will exhibit greater responsiveness to the experimental treatment than middle-income earners. The lower part of Figure 2 reports the effects by income levels, distinguishing between individuals in low, middle-, and high-income households. We find that the effects for the bailout treatments are remarkably similar across the different income groups. If anything, middleincome earners respond somewhat more strongly to the $€ 418$ bn-treatment than high-income and low-income individuals, a pattern that is contrary to what one would expect based on either the tax-hike or the domestic spending arguments. ${ }^{22}$ At the same time, the findings are consistent with the idea that citizens engage in sociotropic evaluations of economic policy.

\footnotetext{
${ }^{22}$ We replicate the analysis using the level of dependence of one's workplace on trade with the EU as the distinguishing category rather than income level. The results reveal no relationship between respondents' trade ties and their sensitivity to the cost of the bailouts. The results are reported in Figure S.1 in the supporting information.
} 


\section{Discussion}

Public opinion on the EU bailouts is widely regarded as a major constraint on government actions in dealing with the crisis. Yet despite the prominent role of public opinion in the ongoing discussions over a coordinated response to the crisis, very little is known about the factors that shape public support toward international financial bailouts. This study provides a first set of insights on this question.

A key finding of this study is that economic selfinterest does not appear to be a major prism by which German citizens assess their country's contribution to the bailouts. The analysis shows that a broad range of measures of individuals' personal economic interests are only weakly associated with their stance on the bailouts, a finding that holds irrespective of respondents' level of knowledge about politics in general or specifically about the crisis. In contrast, the strongest correlates of voters' stance in the bailout debate are measures of their social dispositions, such as their degree of altruism or cosmopolitanism.

A pertinent question arising from these findings is how to evaluate the limited explanatory usefulness of the self-interest measures. One response might be that the bailout issue is not a good test for evaluating selfinterested accounts of individual preferences; given the complexity of the bailout scheme and the high degree of uncertainty regarding its effectiveness, voters may simply lack the ability to assess the likely impact of the policy on their own well-being. Another possible explanation may be the unique role of the media in framing the public debate over this issue. The prolonged campaign carried out by Germany's leading tabloids against the bailouts, including many hyperbolic headlines with overt nationalistic themes, may have marginalized the discussion over the bailouts' domestic distributive consequences.

Although both arguments may have some merit, it is worth noting that our findings are consistent with a growing number of analyses that demonstrate that voters assess economic interaction with foreigners along dimensions that go beyond the strict material consequences of the policies in question. In fact, nonmaterial considerations appear to be more important factors in explaining voter preferences on a range of policies associated with economic openness, including trade, foreign direct investment and immigration (Bechtel, Bernauer, and Meyer 2012; Hainmueller and Hiscox 2006, 2010; Hainmueller, Hiscox, and Margalit 2013; Hainmueller and Hopkins 2014; Mansfield and Mutz 2009; Lü, Scheve, and Slaughter 2012; Margalit 2012). Thus, while our results pertain only to a specific policy debate, the accumulating evidence suggests that a meaningful account of mass attitudes on foreign economic policy requires a stronger focus on other factors such as individuals' cultural affinities and otherregarding preferences.

From a policy perspective, the finding that views on the bailouts only weakly reflect self-interested considerations also implies that governments that seek to gain public backing for further bailouts will struggle to do so by simply "buying off" certain domestic constituencies. While voters may be highly sensitive to certain features of the policy in question, altering the domestic distributive effects of the bailouts is unlikely to bring about a significant shift in voters' stance in this debate.

Finally, our results also point to what may become the longer-term political impact of the eurozone crisis. To a large extent, the integration of the EU economies rests on the idea of creating not just an economic union, but also a group of people with a shared sense of community and affinity. However, this sense of community may be one of the most direct victims of the ongoing crisis. Instead of a shared sense of community, nationalistic, and ethnic sentiments appear to be on the rise, as politicians in both donor and recipient countries frequently engage in language that stereotypes and demeans the other. This process may result in a vicious cycle, where growing animosity among the different publics leads to a weaker commitment among governments to assist the region's struggling countries, leading to deeper economic malaise and making further financial assistance transfers ever more difficult from a political standpoint. Therefore, in the debate over additional bailouts to the region's indebted economies, what is on the line is probably no less than the stability and success of the European integration project for years to come.

\section{References}

Alesina, Alberto, and Eliana La Ferrara. 2005. "Preferences for Redistribution in the Land of Opportunities." Journal of Public Economics 89(5-6): 897-931.

Bechtel, Michael M., Thomas Bernauer, and Reto Meyer. 2012. "The Green Side of Protectionism: Environmental Concerns and Three Facets of Trade Policy Preferences." Review of International Political Economy 19(5): 837-66.

Broz, J. Lawrence. 2005. "Congressional Politics of International Financial Rescues." American Journal of Political Science 49(3): 479-96.

Corneo, Giacomo, and Hans Peter Grüner. 2002. "Individual Preferences for Political Redistribution." Journal of Public Economics 83(1): 83-107.

Curtis, K. Amber, Joseph Jupille, and David Leblang. 2012. "I Save for Icesave: Self-Interest and Sovereign Debt Resettlement." International Organization. Forthcoming. SSRN working paper. 
Downs, Anthony. 1957. An Economic Theory of Democracy. New York: Harper and Brothers.

Druckman, James N. 2001. "The Implications of Framing Effects for Citizen Competence.” Political Behavior 23(3): 22556.

Dye, T. R. 1963. "The Local-Cosmopolitan Dimension and the Study of Urban Politics." Social Forces 41(3): 239-46.

Elster, Jon. 2006. "Altruistic Behavior and Altruistic Motivations." In Handbook of the Economics of Giving, Altruism, and Reciprocity, ed. Serge-Christophe Kolm and Jean Mercier Ythier. Elsevier. 183-206.

Fehr, Ernst and Klaus M. Schmidt. 2006. "The Economics of Fairness, Reciprocity and Altruism: Experimental Evidence and New Theories." In Handbook of the Economics of Giving, Altruism and Reciprocity, ed. Ernst Fehr and Klaus M. Schmidt. Elsevier. 615-91.

Gabel, Matthew J. 1998. "Economic Integration and Mass Politics: Market Liberalization and Public Attitudes in the European Union." American Journal of Political Science 42(3): 936-53.

Gomez, Brad T., and J. Matthew Wilson. 2001. "Political Sophistication and Economic Voting in the American Electorate: A Theory of Heterogeneous Attribution." American Journal of Political Science 45(4): 899-914.

Hainmueller, J. 2012. "Entropy Balancing for Causal Effects: A Multivariate Reweighting Method to Produce Balanced Samples in Observational Studies." Political Analysis 20(1): 25-46.

Hainmueller, J., and D. Hopkins. 2014. "The Hidden American Immigration Consensus: A Conjoint Analysis of Attitudes Toward Immigrants." American Journal of Political Science (forthcoming).

Hainmueller, Jens, and Michael J. Hiscox. 2006. "Learning to Love Globalization: Education and Individual Attitudes toward International Trade." International Organization 60(2): 469-98.

Hainmueller, Jens, and Michael J. Hiscox. 2007. "Educated Preferences: Explaining Attitude Toward Immigration in Europe." International Organization 61(2): 399-442.

Hainmueller, Jens, and Michael J. Hiscox. 2010. "Attitudes toward Highly Skilled and Low-skilled Immigration: Evidence from a Survey Experiment." American Political Science Review 104(1): 1-24.

Hainmueller, Jens, Michael J. Hiscox, and Yotam Margalit. 2013. "Do Concerns about Labour Market Competition Shape Attitudes Toward Immigration? New Evidence from U.S. Workers." MIT Political Science Department Research Paper No. 2011-20.

Hainmueller, Jens, and Yiqing Xu. 2013. "EBALANCE: Stata Module to Perform Entropy Reweighting to Create Balanced Samples." Journal of Statistical Software 54(7): 1-18.

Hays, Jude C., Sean D. Ehrlich, and Clint Peinhardt. 2005. "Government Spending and Public Support for Trade in the OECD: An Empirical Test of the Embedded Liberalism Thesis." International Organization 59(2): 473-94.

Hix, Simon. 1999. "Dimensions and Alignments in European Union Politics: Cognitive Constraints and Partisan Responses.” European Journal of Political Research 35(1): 69106.
Holsti, Ole R., and James N. Rosenau. 1990. "The Structure of Foreign Policy Attitudes among American Leaders." Journal of Politics 52(1): 94-125.

Hooghe, Lisbet, Gary Marks, and Carole Wilson. 2002. "Does Left/Right Structure Party Positions on European Integration?" Comparative Political Studies 35(8) :965-89.

Hurwitz, Jon and Mark Peffley. 1987. "How Are Foreign Policy Attitudes Structured? A Hierarchical Model.” American Political Science Review 81(4): 1099-1120.

Lü, X., K. F. Scheve, and M. J. Slaughter. 2012. "Inequity Aversion and the International Distribution of Trade Protection." American Journal of Political Science 56(3): 638-55.

Lupia, Arthur. 1994. "Shortcuts Versus Encyclopedias: Information and Voting Behavior in California Insurance Reform Elections." American Political Science Review 88(1): 63-76.

Mansfield, Edward D. and Diana C. Mutz. 2009. "Support for Free Trade: Self-Interest, Sociotropic Politics, and Out-Group Anxiety." International Organization 63(3): 425-57.

Margalit, Yotam. 2011. "Costly Jobs: Trade-related Layoffs, Government Compensation, and Voting in U.S. Elections." American Political Science Review 105: 166-88.

Margalit, Yotam. 2012. "Lost in Globalization: International Economic Integration and the Sources of Popular Discontent1.” International Studies Quarterly 56(3): 484-500.

Markowski, Radoslaw, and Joshua A. Tucker. 2005. "Pocketbooks, Politics, and Parties: The 2003 Polish Referendum on EU Membership.” Electoral Studies 24(3): 409-33.

Mayda, Anna Maria. 2008. "Why Are People More Pro-Trade than Pro-Migration." Economics Letters 101(3): 160-63.

Mayda, Anna Maria, and Dani Rodrik. 2005. "Why Are Some People (and Countries) More Protectionist Than Others?" European Economic Review 49(6): 1393-430.

Merton, R.K. 1968. Social Theory and Social Structure. New York: Free Press.

Milner, Helen V., and Dustin H. Tingley. 2011. "Who Supports Global Economic Engagement? The Sources of Preferences in American Foreign Economic Policy." International Organization 65(1): 37-68.

Noël, Alain, and Jean-Philippe Thérien. 2008. Left and Right in Global Politics. Cambridge: Cambridge University Press.

O’Rourke, Kevin H., and Richard Sinnott. 2001. What Determines Attitudes Towards Protection? Some Cross-Country Evidence. In Brookings Trade Forum 2001, ed. Susan M. Collins and Dani Rodrik. Washington, DC: Brookings Institute Press, 57-206.

Quinn, Dennis P., and A. Maria Toyoda. 2007. "Ideology and Voter Preferences As Determinants Of Financial Globalization.” American Journal of Political Science 51(2): 344-63.

Rathbun, Brian C. 2007. "Hierarchy and Community at Home and Abroad. Evidence of Domestic and Foreign Policy Beliefs in American Elits." Journal of Conflict Resolution 51(3): 379407.

Scheve, Kenneth F., and Matthew J. Slaughter. 2001a. "Labor Market Competition and Individual Preferences Over Immigration Policy." Review of Economics and Statistics 83(1): 133-45. 
Scheve, Kenneth F., and Matthew J. Slaughter. 2001b. "What determines Individual Trade-Policy Preferences?” Journal of International Economics 54: 267-92.

Scheve, Kenneth, and Matthew J. Slaughter. 2004. "Economic Insecurity and the Globalization of Production." American Journal of Political Science 48(4): 662-74.

Tucker, Joshua A., Alexander C. Pacek, and Adam J. Berinsky. 2002. "Transitional Winners and Losers: Attitudes Toward EU Membership in Post-Communist Countries." American Journal of Political Science 46(3): 557-71.

Vigna, Stefano Della, John A. List, and Ulrike Malmendier. 2012. "Testing for Altruism and Social Pressure in Charitable Giving.” Quarterly Journal of Economics 127(1): 1-56.
Zaller, John. 1991. "Information, Values, and Opinion.” American Political Science Review 85(4): 1215-37.

\section{Supporting Information}

Additional Supporting Information may be found in the online version of this article at the publisher's website:

An appendix providing information about data, measurement, and coding as well as additional tests that we conducted and that are referenced in the main article. 